\section{Las iglesias de Miguel Fisac}

\section{Miguel Fisac's churches}

\author{
EDUARDO DELGADO ORUSCO
}

https://doi.org/10.17979/aarc.2007.1.0.5021
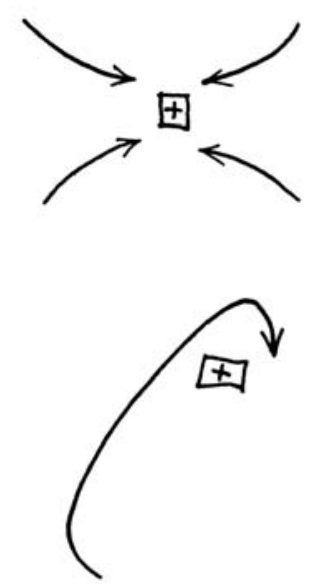

Esquemas teóricos: convergente y muro dinámico.

\section{INTRODUCCIÓN}

Querría empezar agradeciendo sinceramente a los responsables de este Congreso su amable invitación para participar en él. Igualmente querría pedir disculpas sobre el título de la ponencia que figura en el programa que no fue si no una inteligente solución de Esteban Fernández a mi indefinición durante el tiempo disponible antes de editarlo. Finalmente, la oportunidad de un encargo hecho hace unos meses por el Colegio de Arquitectos de Almería en su colección de Archivos de Arquitectura para estudiar una obra de Miguel Fisac, la iglesia parroquial de Santa Ana, me permitió una profunda investigación en la Fundación Miguel Fisac, algunos de cuyos frutos me gustaría compartir aquí hoy.

No obstante, debo confesar que para mí la explicación de la obra de Miguel Fisac no puede ser si no el acercamiento al trabajo de un amigo, de un ser profundamente humano y ejemplar. Cuando en 1997, entre los numerosos reconocimientos que jalonaron los últimos años de la vida de Miguel Fisac, le fue otorgado el Premio Antonio Camuñas de Arquitectura, el jurado encargado de concedérselo valoró como una de las razones de mayor peso sus aportaciones en el terreno de la arquitectura religiosa ${ }^{1}$.

En efecto, y al margen de su enorme contribución a la superación del modelo historicista que triunfó en la arquitectura de la posguerra española, si hay un arquitecto protagonista en el proceso de desarrollo de los edificios religiosos que tuvo lugar durante la segunda mitad del siglo $\mathrm{XX}$ en nuestro país, ese es, sin lugar a dudas, Miguel Fisac. A ello contribuyó fundamentalmente la profusa sucesión de encargos de este tipo que tuvo a lo largo de prácticamente toda su vida. Igualmente, su afición al debate y a la escritura, terminaron de configurar un cuerpo intelectual que le hacen merecedor de la mencionada condición protagonista.

\section{Introduction}

I would like to start by thanking sincerely the conference organisers for having invited me to take part in it. I would also like to apologise for the paper title included in the programme, which was an intelligent solution by Esteban Fernández to my lack of definition during the time available before the edition. Finally, I had the chance to do a thorough research at Miguel Fisac Foundation as a result of an assignment made a few months ago by the Association of Architects of Almeria in order to study a work by Miguel Fisac, Saint Anne's parish church. Today I would like to share with you some of the fruits of my research. Nevertheless, I must confess that for me, explaining Miguel Fisac's work is about explaining a friend's work, the work of a deeply humane and exemplary person. In 1997, among the numerous acknowledgements received during the last years of Miguel Fisac, he was awarded the Antonio Camuñas Architecture Prize and the corresponding jury assessed as one of his greatest contributions his religious architecture works ${ }^{1}$.

Certainly, and apart from his huge contribution to overcoming the historicist model which succeeded in the post-war Spanish architecture, Miguel Fisac was undoubtedly the protagonist of the development process of religious buildings which occurred in our country during the 2nd half of the 20 th century. The fact is that the huge number of religious architecture assignments that he received throughout his career certainly contributed to that. Simultaneously, his interest in debate and writing also contributed to the configuration of 


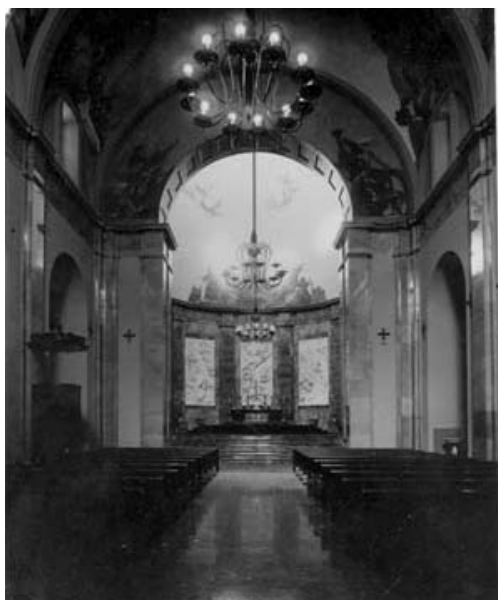

an intellectual body which made him deserve his already mentioned status of protagonist.

This status would justify the attention paid to his work, understood as a continuum where each new project receives the achievements of the previous ones, and is also the object of an intense experimentation. Fisac appears as an obsessive architect who produced numerous variations in his ongoing attempt to improve. This status justifies my paper which is not dedicated to Saint Anne, but to the ideal church that Fisac searched for during his whole career and never built. I agree with Juan Plazaola that «if you analyse the sacred architecture designed by Fisac throughout his extended career, you will see that he made a decisive step at this church of Moratalaz towards the ideal church of our times» ${ }^{2}$. Thus, Saint Anne could be understood as the summit, the peak of his career, an interim decantation of his research in this field in the mid 60s.

\section{Overture}

Born in Daimiel in 1913, Miguel Fisac got his Degree in Architecture at the Architecture School of Madrid in 1942. Linked to Opus Dei since 1935, his first professional steps were linked to the launch and development of the Higher Council of Scientific Research which had been entrusted to other members of that Catholic trend -then a minority but emerging one-in our country.

Let us focus in our story on the CSIC chapel —also known as Holy Ghost parish - since this was the first step in the career of the architect from $\mathrm{La}$ Mancha. Fisac, who had started his professional development, even before completing his studies,

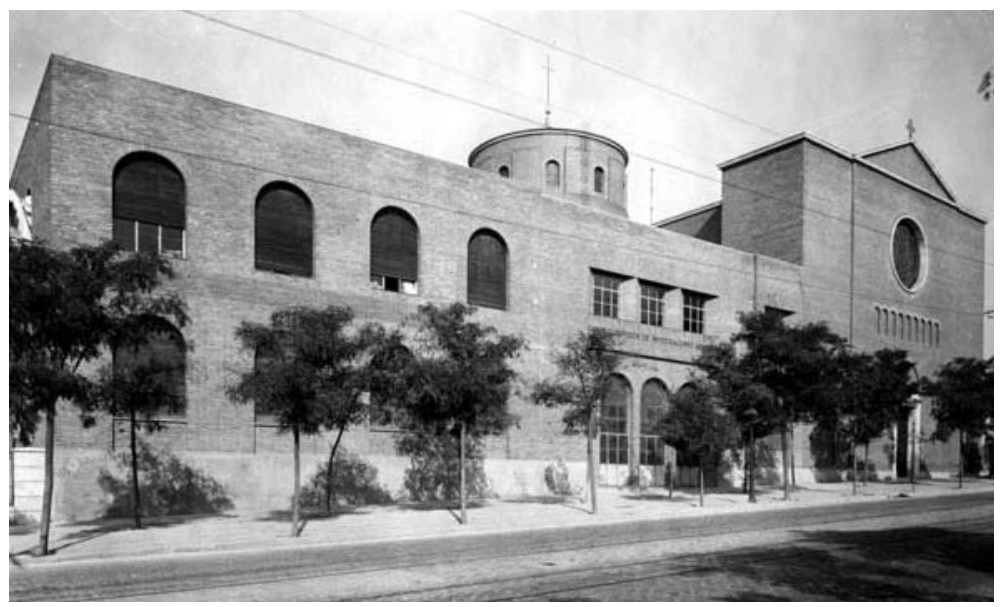

Iglesia parroquial del Espíritu Santo (Capilla del CSIC), Madrid (1942/48).

Esta condición justificaría la atención a su obra, entendida como un continuo en el que cada nuevo proyecto se convierte en receptor de los logros de los anteriores y a la vez, en campo de intensa experimentación. Fisac se nos muestra como un arquitecto obsesivo, productor de numerosas variaciones en un constante intento de superación. Esta condición es la que justifica esta ponencia, dedicada, antes que a Santa Ana, a la iglesia ideal que Fisac persiguió durante toda su carrera profesional y que, cabe decirlo, no llegó a construir. Con Juan Plazaola cabría apuntar que «quien analice la arquitectura sagrada diseñada por Fisac en el curso de su dilatada vida profesional, podrá verificar que en esta iglesia de Moratalaz se ha dado un paso decisivo hacia la iglesia ideal de nuestra época» ${ }^{2}$. Así, Santa Ana podría entenderse como la cumbre, el momento de mayor intensidad en su carrera, decantación provisional, mediada la década de los sesenta, de sus investigaciones en este terreno.

\section{OBERTURA}

Nacido en Daimiel en 1913, Miguel Fisac obtuvo su título de arquitecto en la Escuela de Arquitectura de Madrid en 1942. Ligado desde 1935 al Opus Dei, sus primeros pasos profesionales se vincularon a la puesta en marcha y desarrollo del Consejo Superior de Investigaciones Científicas, que había sido confiado a otros miembros de esa - entonces minoritaria aunque emergente - corriente católica en nuestro país.

Para nuestra historia, interesa detenernos en la capilla del CSIC - también conocida como parroquia del Espíritu Santo-, por ser el primer paso en la carrera del arquitecto manchego. Fisac, que había empezado su desarrollo profesional -incluso antes de terminar sus estudios - de la mano del arquitecto Ricardo Fernández-Vallespín en el proyecto y dirección de obra del Instituto «Torres Quevedo», construyó también para el CSIC, además del fabuloso conjunto de la Colina de los 


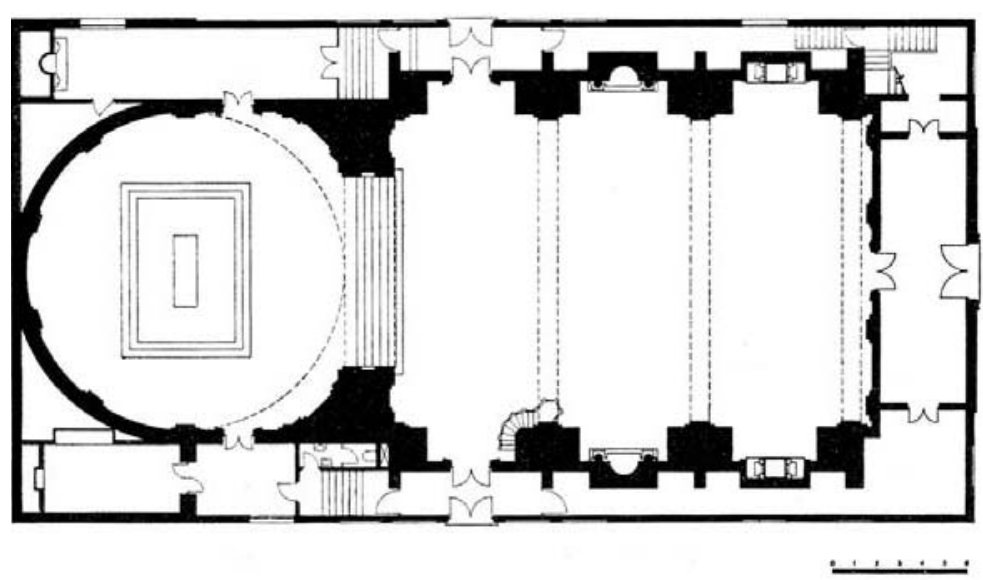

Iglesia parroquial del Espíritu Santo (Capilla del CSIC), Madrid (1942/48).

Chopos, un par de pequeñas ermitas de montaña — una en los Pirineos y la otra en la sierra de Guadarrama - que carecen de entidad para ser tratadas particularizadamente, pues repiten esquemas populares de escaso interés.

El proyecto de la capilla del CSIC en la Colina de los Chopos consistió originalmente en el aprovechamiento de los tres primeros metros del muro perimetral del auditorio del Instituto-Escuela, obra de Carlos Arniches y Martín Domínguez, que tras la guerra se encontraba arruinado. El arquitecto propuso una intervención sobria pero con carácter. Él mismo explicaba sus fuentes e intenciones: «Una adaptación de un auditorio a iglesia del Espíritu Santo y después del edificio central del CSIC y otros edificios para institutos de investigación, formaron un conjunto axial que proyecté y gustó. Entonces (1942-1945) pareció rabiosamente moderno. Y al terminar, después de haber adquirido un profundo conocimiento de la arquitectura clásica, en especial de la del Quattrocento y Cinquecento italianos, enseñanza que siempre he creído - también ahora- que me proporcionó una base segura en mi formación estética arquitectónica, al terminar aquellas obras con éxito y a mi gusto, me di cuenta, sin necesidad de ningún discurso intelectual, que aquél no era un camino; que por allí no se iba a ninguna parte» ${ }^{3}$.

El resultado fue una pequeña iglesia, no obstante de notable influencia en el panorama arquitectónico de la época, que ya apuntaba el tipo conceptual «místico» —en la catalogación que Luis Moya emplearía años más tarde para clasificar los proyectos presentados al concurso de la iglesia parroquial de San Esteban Protomártir en Cuenca ${ }^{4}$ - presentando precisamente la capilla del CSIC como ejemplo. Interiormente se trataba de un espacio de una sola nave - sin crucero- en la que el deambulatorio se llevó al exterior del espacio sacro en forma de pasillos perimetrales. Se puede señalar una cierta falta de proporción entre el espacio destinado a los fieles y el presbiterio. Esa desproporción se with the architect Ricardo Fernández-Vallespin in the project and work management of the Torres Quevedo High School, he also built for the CSIC, apart from the fabulous complex of Colina de los Chopos, a couple of tiny mountain hermits (one at the Pyrenees and another one at Guadarrama ridge) which lack entity in order to be covered in detail, since they repeat scarcely interesting popular schemes.

The project for the CSIC chapel in Colina de los Chopos consisted originally of making the most of the first $3 \mathrm{~m}$ of the perimeter wall of the high-school arena, a work by Carlos Arniches and Martin Dominguez, which was derelict after the war. The architect proposed a sober though full of character intervention. He explained his sources and intentions: "An adaptation of an arena and church of the Holy Ghost and, after the CSIC main building and other buildings for research institutes, they integrated an axial complex projected and liked by me. Then, in (1942-1945) it looked furiously modern. And when I finished, after getting a deep knowledge of classical architecture, specially that of the Italian Quattrocento and Cinquecento - a teaching which I believed and still believe that gave me a solid basis for my architectural aesthetic training - when I finished those works successfully and to my taste, I realised without needing any sort of intellectual discourse that it was not my way; that it led nowhere» ${ }^{3}$.

The result was a small church which had a considerable impact on that time's architectural scenario. It already pointed at the mystical conceptualtype - according to the classification used by Luis Moya some years later for the projects submitted to the contest of Saint Stephen Protomartyr's church in Cuenca ${ }^{4}$ - presenting precisely the CSIC chapel as an example. The interior was a space with one nave, no crossing, where the ambulatory was taken to the outside of the sacred space in the form of perimeter corridors. A certain lack of proportion can be noted between the space for the faithful and the presbytery. This lack of proportion would show even more outside, where the presbytery was planned as formally contained in a huge cylindrical tambour ${ }^{5}$. This tambour was planned as pierced at the top, searching for an effect developed by the author throughout his work: over-lighting the presbytery and leaving the faithful nave in murkiness for contrast.

The constructive process was the most remarkable thing for its author. Certainly, the lack of iron and other materials which characterised the Spanish post-war era led Fisac to experiment with some quasi-artisanal domes with four vertical plans, though with a mixed solution using armoured 
concrete for the arches, which showed the invention of the architect from La Mancha: "I have adopted the constructive solutions which were the cheapest, apart from having the necessary stability requirements. It should be noted that, currently, the lack of iron is a very important factor to be born in mind, as well as the fact of saving big amounts of other materials. Avoiding the use of small amounts of iron for compensating a dome thrusts is not economical, since it requires building big brick, concrete or stone buttresses which are much more expensive. "The solution used for building the domes was to create four armoured concrete arches (two transverse and two longitudinal ones), a rectangular precinct in the plan and covering this space with a dome with four vertical plans, partitioned with long thin bricks, which can be easily made with a simple flying skeleton whose position can be established at any time by the length of a radius going from the materialised centre of the sphere to which the dome belongs» ${ }^{6}$. The truth is that, with regard to the furnishings, Juan de Adsuara's relieves and Ramón Stolz's frescoes are a figuratively academic contribution, detached from the innovative collaborations from which later works by Miguel Fisac benefited.

Anyhow, if we make an effort to place ourselves at the time of building, we will understand why it was accepted as an example of modernity. The heirloom of $3 \mathrm{~m}$ of naked perimeter wall made of simple brick, of the high-school arena by Arniches and Dominguez, as well as young Fisac's intuition were enough to achieve a well-balanced exterior, halfway between the abstraction coming from the Italian fascist architecture and the rank taste of our tradition. As it was mentioned, the interior is perhaps the less perfect part of the building. Fisac tried a more conventional solution by using giant marble orders superimposed on the building structure.

\section{Adagio}

In the 50s, travelling became the best antidote against the isolation and cultural mediocrity which had reigned in Spain in the previous decade. Therefore, it is well known that Sáenz de Oiza stayed in the USA while Miguel Fisac did so in the Scandinavian countries. Cano Lasso became acquainted with the Dutch rationalism during a trip to Hilversum in 1949. Gutiérrez Soto also travelled to the USA and Brazil in the same year. Other architects, such as Ramón Vázquez Molezún, Javier Carvajal or José María Garcia de Paredes enjoyed grants in Rome, and the latter devoted a couple of years to getting to know the main European architecture. manifestaría todavía con más claridad al exterior, donde el presbiterio se planteaba contenido formalmente en un tambor cilíndrico de gran presencia ${ }^{5}$. Ese tambor se proyectó perforado en la parte más alta, buscando un efecto que el autor desarrollaría a lo largo de su obra: la sobreiluminación del presbiterio, dejando, por contraste, la nave de los fieles en una semipenumbra.

Lo más destacable — para su autor- había sido el proceso constructivo. En efecto, la carencia de hierro y otros materiales que caracterizó la posguerra española llevó a Fisac a ensayar unas bóvedas vaídas de construcción cuasi-artesanal, aunque en una solución mixta con empleo de hormigón armado en los arcos, que ya apuntaba la capacidad inventiva del arquitecto manchego: «Constructivamente se han adoptado las soluciones que, a más de reunir las condiciones de estabilidad necesarias, fueran las más económicas. Y hay que advertir, que si en los momentos actuales la escasez de hierro es un factor importantísimo a tener en cuenta, no lo es menos el ahorro de grandes masas de otros materiales. Evitar el empleo de pequeñas cantidades de hierro en la compensación de empujes de una bóveda, por ejemplo, no es económico, pues exige tener que construir grandes contrafuertes de ladrillo, de hormigón o de piedra, cuyo coste resulta mucho más elevado.

»La solución adoptada para la construcción de las bóvedas ha sido formar con cuatro arcos (dos fajones y dos formeros) de hormigón armado, un recinto rectangular en planta, cubriendo este espacio con una bóveda vaída, tabicada de rasilla, que se construye con toda facilidad con una simple formaleta volante cuya situación puede ser fijada en todo momento por la longitud de un radio que parte del centro materializado de la esfera de que forma parte la bóveda» ${ }^{6}$.

Lo cierto es que en el capítulo de los acabados, los relieves de Juan de Adsuara y los frescos de Ramón Stolz resultan una aportación figurativamente académica, lejos de las renovadoras colaboraciones que recibirían otras futuras obras de Miguel Fisac.

En cualquier caso, si hacemos el esfuerzo de situarnos en el momento de su edificación, comprenderemos que efectivamente fuera tenida como ejemplo de modernidad. La herencia de tres metros perimetrales de muro desnudo, de mero ladrillo, del auditorio del Instituto-Escuela de Arniches y Domínguez, y la intuición del joven Fisac, fueron suficientes para conseguir un equilibrado exterior, a medio camino entre la abstracción proveniente de la arquitectura fascista italiana y el sabor rancio de nuestra tradición; en el interior — como queda dicho, puede que lo menos conseguido del conjunto- Fisac ensayó una solución más convencional con el uso de órdenes gigantes de mármol sobrepuestos a la estructura del edificio.

\section{ADAGIO}

Al filo de la década de los cincuenta, el viaje se convirtió en el mejor antídoto contra el aislamiento y la precariedad cultural que habían dominado la década anterior en nuestro país. Así, son ya míticas, entre otras, las 
estancias de Sáenz de Oíza en Estados Unidos y de Miguel Fisac en los países nórdicos. Cano Lasso tuvo conocimiento del racionalismo holandés en un viaje a Hilversum en 1949. También Gutiérrez Soto viajó ese mismo año a Estados Unidos y Brasil. Otros arquitectos como Ramón Vázquez Molezún, Javier Carvajal o José María García de Paredes disfrutaron de estancias becadas en Roma, y éste último dedicó dos años a conocer las principales arquitecturas europeas.

Tras su estancia en tierras nórdicas ${ }^{7}$ en busca de experiencias útiles en la preparación del proyecto del Instituto Cajal de Microbiología, el arquitecto sufrió una crisis, una suerte de catarsis que le llevó desde el intento de actualización del clasicismo ensayado en la Colina de los Chopos - que él mismo consideraba fallido - hacia posturas organicistas, una de cuyas primeras expresiones fue el proyecto de la librería del CSIC en la calle Medinaceli de Madrid, y probablemente la mejor entre esas primeras obras, el Instituto Laboral de Daimiel, de 1951. Fisac, por entonces muy interesado en la obra de tipo religioso, comenzaba así un largo camino que habría de proporcionar a la arquitectura española algunos de los mejores espacios de este tipo.

En efecto, el arquitecto manchego ya había levantado su vehemente voz para criticar, a finales de los años cuarenta, la evolución de la arquitectura española en diversos artículos y publicaciones ${ }^{8}$. Esa voluntad de búsqueda, valiente para quien había proyectado y construido con notable éxito en el panorama cultural de la época el ambicioso complejo del CSIC en la madrileña Colina de los Chopos, le llevó a ser una de los principales firmantes del Manifiesto de La Alhambra en $1953^{9}$.

Pero además, el compromiso personal de Fisac con la arquitectura de carácter sacro le llevó a tratar esta temática en algunos de los artículos señalados. Particular interés reviste el publicado en Árbor, la revista del CSIC, en la que, en fecha tan temprana como 1949, estaba enunciando - puede que sin ser todavía completamente consciente del alcance de sus afirmaciones - el camino a seguir: la solución convergente. Por la trascendencia de este recurso en la obra del autor y por su influencia en la evolución del espacio sacro español de los años cincuenta y sesenta — precisamente hasta el Concilio Vaticano II, cuando el mismo Fisac volvería a señalar el norte proyectual con su «desdoblamiento en varios focos» de la atención sobre el presbiterio en el proyecto de la iglesia parroquial de Santa Ana de Moratalaz - recojo aquí íntegramente el razonamiento fisaquiano:

«QQué planta será la más adecuada para una iglesia moderna?

»(...) La planta de cada recinto de un templo ha de tener un punto singular y destacado en donde se sitúa el altar. Como, por otra parte, ese punto privilegiado tiene que tener una dirección principal, la normal al altar y en un solo sentido, tanto si la misa se celebra cara al pueblo como si se celebra de espaldas a él, queda descartada la solución circular de planta, ya que ésta no tiene más que un punto singular, el centro, pero todas las direcciones tienen ejes de la misma importancia.

»La solución de planta elíptica tiene un eje privilegiado: el eje mayor; pero los puntos singulares, los focos, no son puntos extraordinariamente
After staying in the Scandinavian countries ${ }^{7}$ in search of useful experiences for preparing the project for the Cajal Institute of Microbiology, the architect suffered a crisis, some sort of catharsis who took him from his attempt to update the classicism tried in Colina de los Chopos - considered by him as a failure- towards organic positions. One of the first examples was the project for the CSIC bookshop in Medinaceli Street of Madrid. Among those first works, probably the best one was the Labour Institution of Daimiel, in 1951. Fisac, who was by then very interested in religious works, started a long path that would contribute to the Spanish architecture with some of the best spaces of that kind.

Certainly, the architect from La Manch a had already raised his passionate voice in order to criticise the evolution of Spanish architecture in several papers and publications in the late $40 s^{8}$. This will to search, which was something courageous for somebody who had made the project and built quite successfully in the cultural scenario of that time the ambitious CSIC complex in the Madrid Colina de los Chopos, led him to become one of the main signatories of the Alhambra Manifesto in $1953^{9}$.

Moreover, Fisac's personal commitment to sacred architecture led him to tackle this subject in some of the already mentioned papers. The one published in Arbor, the CSIC magazine, is particularly interesting. The path to be followed was marked as early as 1949, maybe without a full realisation of the scope of his statement: the convergent solution. Due to the transcendence of this resort in the author's work, and due to its impact on the evolution of the Spanish sacred space in the 50s and 60s, I would like to repeat Fisac's whole reflection here. This resort reached the II Vatican Council, when Fisac reiterated the goal of the project with its doubling of the attention in several foci about the presbytery of Saint Anne's parish church in Moratalaz. "What is the best plan for a modern church? »(...) The plan of each precinct in a temple must have a singular and outstanding point where the altar is located. Since that privileged point must have a main direction, the normal one towards the altar and in a single direction, whether mass is celebrated before the people or with backs turned to it, the circular plan solution is discarded. The reason is that it has only one singular point, the centre, but every direction has equally important axes.

"The elliptical plan solution has a privileged axis: the main one; but the singular points, the foci, are not extraordinarily highlighted whose singular position can be marked by sight. Moreover, if 


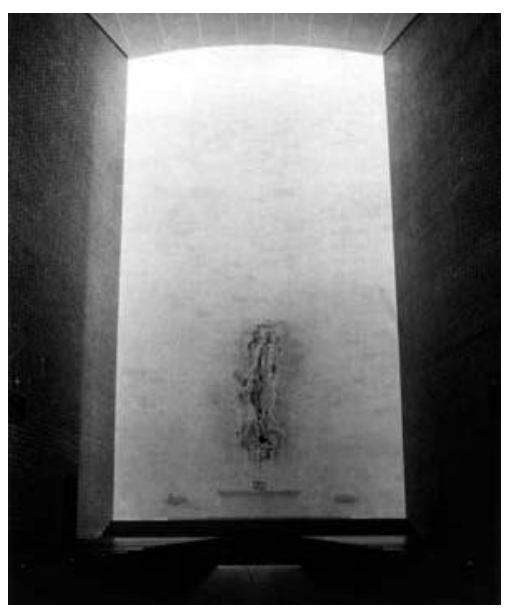

the altar is placed at one of them, the other one remains useless, devoid of content.

»The rectangular plan marks a much defined axis but with no main points in it.

"It is obviously necessary to resort to a plan composed of an important high part marking the altar, the apse, and that could be round, square or in any simple form. The other part, corresponding to the believers, is markedly axial, either rectangular with its bigger axis coming from the centre of the apse or in a fan with a maximum angle opening of 30 or 45 degrees, so that the altar remains visibly at the front. Maybe the fan nave solution, which might seem unpleasant at first sight, since it strays from the classical solutions for church plans, would be the fittest for big temples» ${ }^{10}$.

As it was mentioned, the so-called convergent solution would be central in the recent history of Spanish sacred architecture. Actually it had been and still was profusely used abroad, particularly for the reconstruction of Germany's church heritage ${ }^{11}$. But, regardless of the fact that Fisac reached this principle in a theoretical way-according to the article quoted - or maybe he came across some example of the said solution abroad ${ }^{12}$, the merit of being the first one to state it in Spain, as well as the first one to apply it is undoubted ${ }^{13}$.

Nevertheless, the first attempt of this sort occurred in $1951^{14}$, in the never built project for the chapel of the already mentioned Labour Institution of Daimiel. This project heralded with striking similarity the church of the

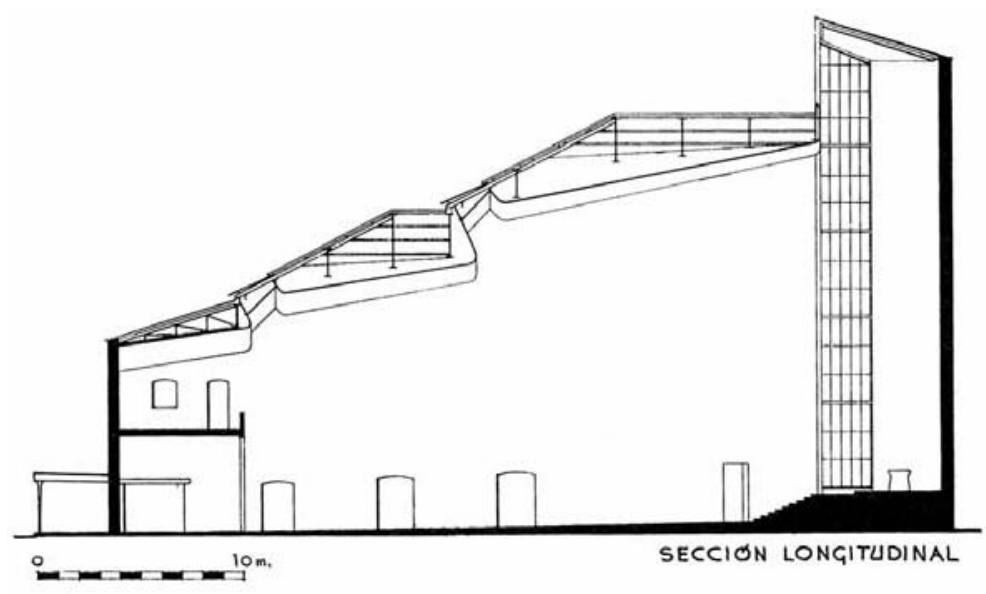

Colegio Apostólico de Arcas Reales, Valladolid (1952/55).

resaltados que se pueda marcar a simple vista su posición singular, y, además, si en uno de ellos se coloca el altar, el otro queda sin contenido, sin razón de ser.

»La planta rectangular marca un eje muy definido, pero sin ningún punto principal en él.

»Es evidente la necesidad de recurrir a una planta compuesta de una parte importante y elevada que marque el altar, el ábside y que pueda ser circular, cuadrado o de otra forma simple, y otra parte, la de los fieles, marcadamente axial, bien rectangular con su eje mayor partiendo del centro del ábside, o bien en abanico, con una apertura angular de 30 ó 45 grados como máximo, para que el altar quede situado sensiblemente de frente. Quizá la solución de la nave en abanico, que a primera vista puede repugnarnos porque se desvía bastante de las soluciones clásicas de plantas de iglesias, sea la más adecuada para grandes templos» ${ }^{10}$.

Como queda dicho, el llamado recurso convergente habría de resultar capital en la historia reciente de nuestra arquitectura sacra. Lo cierto es que ya había sido y estaba siendo empleado con profusión en el extranjero, particularmente en la reconstrucción del patrimonio eclesiástico en Alemania ${ }^{11}$. Pero con independencia de que Fisac llegase a este principio de un modo teórico - como manifiesta el artículo citado - o que hubiese conocido algún ejemplo de esta solución fuera de nuestras fronteras ${ }^{12}$, nadie puede negarle el mérito de haber sido el primero en enunciarlo en nuestro país, e igualmente, el primero en aplicarlo ${ }^{13}$.

No obstante, el primer ensayo en este sentido no tendría lugar hasta $1951^{14}$, en el proyecto - no construido - de capilla para el mencionado Instituto Laboral de Daimiel. Este proyecto anunciaba, con llamativa semejanza, la iglesia del complejo de Arcas Reales, en Valladolid, proyectado y construido apenas un año después para la Provincia de Nuestra Señora del Rosario de Filipinas de la Orden de Santo Domingo ${ }^{15}$. 


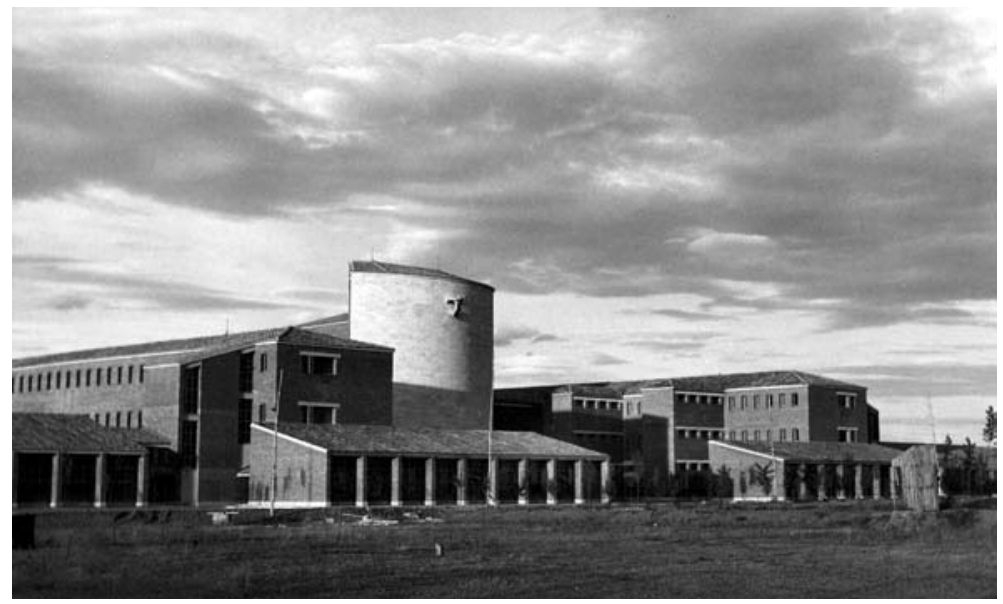

Colegio Apostólico de Arcas Reales, Valladolid (1952/55).

En efecto, fue en sendos proyectos para los dominicos donde Fisac ensayó y verificó el recurso teóricamente ya enunciado - como hemos visto- en 1949. Se trata de Arcas Reales en Valladolid, y de San Pedro Mártir en Alcobendas-Madrid. En estas obras puede leerse un esfuerzo de paulatino desprendimiento de algunas reminiscencias de su formación clásico-académica — como el recurso a una cierta axialidad ortogonal—, al tiempo que manifestaba en qué medida iba incorporando - interiorizando- el lenguaje abstracto de la Modernidad.

No obstante, en la revisión de la Sesión de Crítica de Arquitectura organizada por Carlos de Miguel y dedicada precisamente a la iglesia de Arcas Reales ${ }^{16}$ resulta sorprendente la frialdad — posible manifestación de escasa aceptación - con que fue recibida por otros arquitectos esta obra, así como la vehemente defensa que planteó Fisac de su modernidad y de los recursos escenográficos y formales a los que había recurrido en su diseño. El arquitecto manchego hacía referencia a los mecanismos empleados como explicación del modo de captar la atención de los fieles y dirigirlos hacia el altar — centro de atención del conjunto-, preocupación generadora de la mencionada evolución fisaquiana. Junto a la convergencia de los muros laterales, el arquitecto ensayó un escalonamiento ascendente de las cubiertas, junto a un ligero ascenso del pavimento, valorado todo ello por la disposición de las entradas de luz al templo, siempre de atrás hacia delante.

Otro de los argumentos del arquitecto manchego en la composición fue el de su austeridad — casi desnudez- de elementos decorativos, y ello a pesar de contar con un elenco de artistas colaboradores únicamente comparable a excepciones como la del santuario de Aránzazu ${ }^{17}$. La postura de Fisac al respecto se recogía en las siguientes palabras: «Venero las imágenes y respeto la ornamentación religiosa en tanto en cuanto son un
Arcas Reales complex in Valladolid, projected and built a year later for the Province of Our Lady of the Rosary in the Philippines of Santo Domingo's Order ${ }^{15}$.

It was certainly in two projects for the Dominicans where Fisac tested and verified the theoretically stated principle of 1949. Se trata de Arcas Reales en Valladolid, y de San Pedro Mártir en Alcobendas-Madrid. These works show an effort to gradually get rid of some reminiscence of his classical-academic education - such as resorting to a certain orthogonal axis-, as well as to what extent he had integrated and interiorised the abstract language of Modernity.

Nevertheless, in a review of the Architecture Critique Session organised by Carlos de Miguel and precisely dedicated to the church of Arcas Reales ${ }^{16}$, it is surprising to see the cold welcome received by the church, possibly a sign of its scarce acceptance, on behalf of other architects. On the other hand, Fisac vehemently defended its modernity and the formal and set-design resources he had used for its design. The architect from La Mancha referred to the mechanisms used as an explanation of the way of catching the believers' attention, directing it to the altar -centre of attention of the whole set-, a concern which gave rise to the already mentioned Fisac's evolution. Together with the convergence of lateral walls, the architect tested an ascending layering of the covers, together with a slight rise of the pavement. All of this was evaluated by the location of light inlets to the temple, always from back to front.

Another argument in composition by the architect from La Mancha was the austerity -almost nakedness - of decoration elements. This was in spite of having a host of collaborating artists which can only be compared to exceptions such as the Aránzazu ${ }^{17}$ sanctuary. Fisac's position in this regard is explained thus: "I worship sculptures and I respect religious ornaments provided that they are a means to get us closer to God; but I detest them if they are at the service of a decoration which is improper for a church, which is often the case» ${ }^{18}$.

The Golden Medal of the Vienna Sacred Art Exhibition of 1954 was granted to the complex of Arcas Reales, which meant one of the first international accolades for Spanish architecture and signalled a path to be followed by the 50s architects, simultaneously affirming its author as one of the most solid realities of that architecture. Salvador Mata talks in detail about the influence of that work when he says that «the model of Fisac's church, because of 
its symbolic values and its spatial innovation, and due to the dissemination that his acknowledgement brought about at the Vienna exhibition, was imitated in a return movement by several German authors of the time working in the Wurzburg diocese; this is specifically related to Hans Schädel in Hasloch» ${ }^{19}$.

As regards Arcas Reales, the Alcobendas project is only three years younger. Although the complex belongs to the same family as the previous one, the church is much more interesting for this study. The space is extraordinary. Fisac achieved one of the best sets in his career.

This project, just like in Arcas Reales, fights to get rid of its orthogonal condition. Nevertheless, there is a tangible innovation in the abandonment of certain fine arts symmetry, still present in the complex from Valladolid, while the church shows a critical point in design intensity. The study of the best grouping of the faithful around the altar - extended concern and engine of the spatial renewal of European sacred architecture - ended up by drawing a hyperbolic plan which was truly revolutionary for its time.

It seems that one of his achievements was, apart from the original liturgical-functional solution: the treatment of light resolved with the help of José Maria Labra by means of stainedglass windows of changing colours according to their position with regard to the presbytery: the further, the colder (blue), and changing to warmer hues (golden) towards the altar. Above it, a natural (white) skylight causing a light tension, which is a real achievement by Fisac. The similarity between the effect pursued above the Alcobendas altar and what Saarinen projected and built in 1957 for the presbytery of the chapel of the MIT in Cambridge (USA) is striking. This shows, rather than an unlikely influence, a similitude in sensitiveness, given that both solutions are contemporary but geographically distant. In this case, some steel wires descend upon the altar holding a big cross by Pablo Serrano which seems to be suspended in mid air, as if halfway between Heaven and Earth like a perfect mediator imbued with the light of grace. This mechanism for presenting the cross, which is in practice the only sculpture surrounding the altar, was adopted by its author as a paradigm which he frequently repeated in the subsequent sacred space projects. ${ }^{20}$

A stained-glass window appears at the back of the nave, behind the choir. It is made according to the canvases by Adolfo Winternitz and it has a remarkable presence in the whole set which was

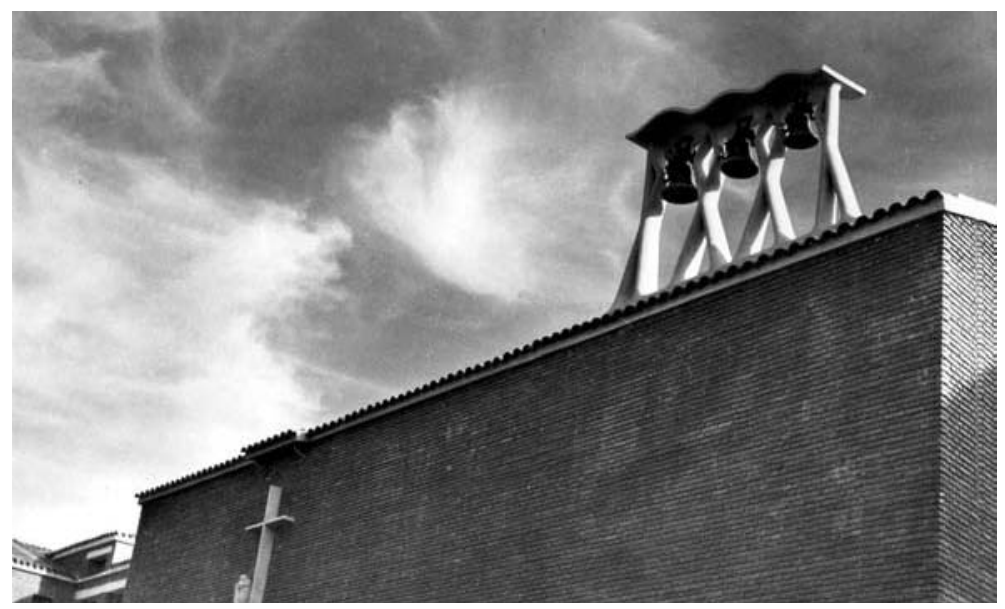

Colegio Apostólico de Arcas Reales, Valladolid (1952/55).

vehículo para acercarnos a Dios; pero las detesto en cuanto se las pone al servicio de un decorativismo impropio de una iglesia, que es lo que se está haciendo en muchos casos» ${ }^{18}$.

La Medalla de Oro de la Exposición de Arte Sacro de Viena de 1954, otorgada al conjunto de Arcas Reales, significó para la arquitectura española uno de sus primeros reconocimientos internacionales, señalando un camino a seguir para los arquitectos de los años cincuenta, a la vez que confirmando a su autor como una de las más firmes realidades de esa arquitectura. De la influencia de esta obra habla con precisión Salvador Mata al señalar que «el modelo de la iglesia de Fisac, en razón de sus valores simbólicos y de innovación espacial y por la difusión que supuso su reconocimiento en la exposición vienesa, fue imitada - en un movimiento por tanto, de ida y vuelta - por varios autores alemanes de aquellos años que trabajaron en el ámbito de la diócesis de Wurzburgo, en concreto, está claramente relacionada con la de Hans Schädel en Hasloch» ${ }^{19}$.

Con respecto a Arcas Reales, Alcobendas es - en proyecto- apenas tres años posterior. Y, si bien el conjunto pertenece a la misma familia que el anterior, la iglesia resulta mucho más interesante para este estudio. El espacio resulta extraordinario, consiguiendo Fisac uno de los conjuntos más logrados de su carrera.

Se trata de un proyecto que, como en Arcas Reales, sólo con dificultades alcanza a librarse de la ortogonalidad. No obstante, hay un avance tangible en el abandono de cierta simetría beaux-artiana, presente todavía en el conjunto vallisoletano, mientras la iglesia muestra un punto crítico de intensidad de diseño. El estudio de la mejor agrupación de los fieles alrededor del altar - preocupación con gran presencia y motor de la renovación espacial de la arquitectura sacra en Europa - acabó dibujando una planta hiperbólica, verdaderamente revolucionaria para su momento. 

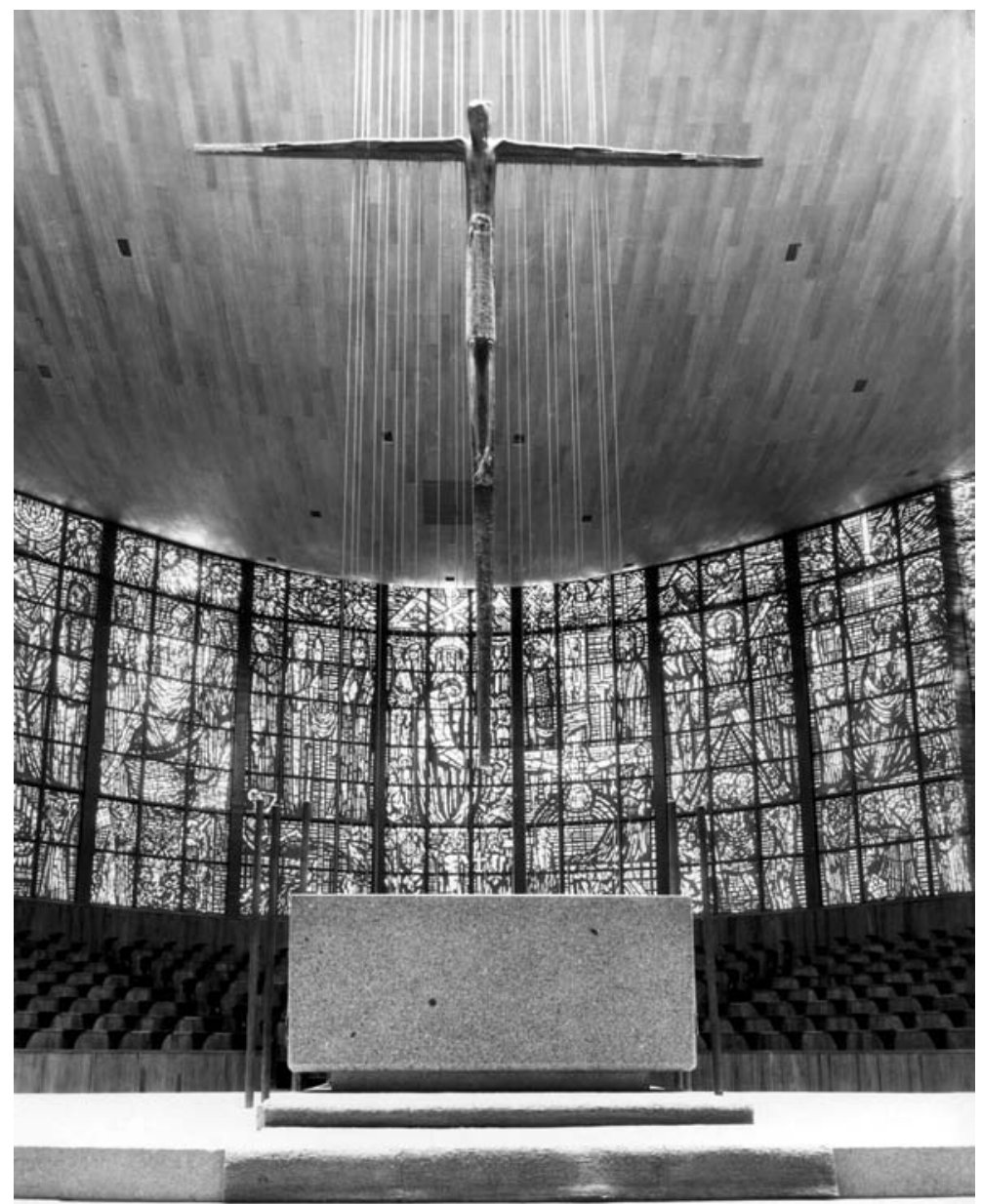

Teologado de San Pedro Mártir. Alcobendas, Madrid (1955/60). Arriba, presbiterio de la iglesia, con el Crucificado de Pablo Serrano y los vitrales de Adolfo Winternitz al fondo. Abajo, Planta.

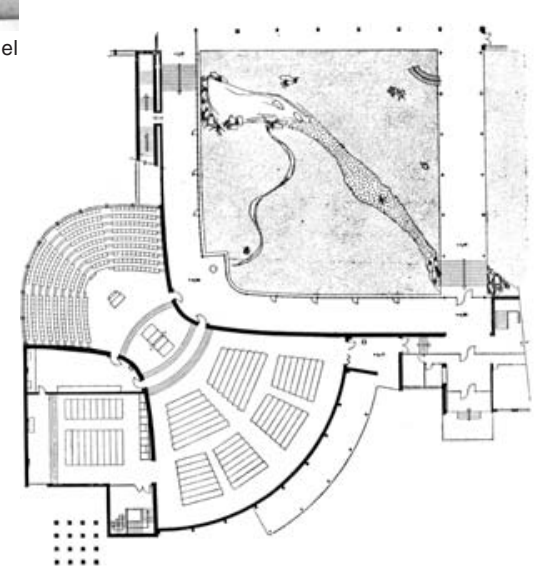




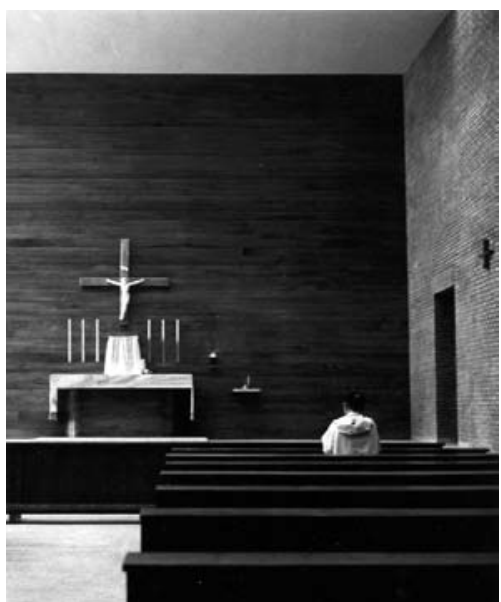

Teologado de San Pedro Mártir. Alcobendas, Madrid (1955/60). Capilla para la reserva eucarística.

disliked by the author ${ }^{21}$. However, it was never too dazzling, since the natural skylight above the presbytery always generates a more intense lighting than the one from the back. The scenes stand for Saint Peter of Verona's martyrdom. He was the first Dominican martyr and the one to whom the building is devoted. Its drama complements very well the overall atmosphere of the temple. In spite of the architect's already mentioned dislike, this stained-glass window, together with the remaining artistic collaborations, is an excellent example of the figurative paths followed by the sacred art of the times. It certainly contributes to the configuration of an excellent example which is a milestone in the history of the renewal of modern Spanish architecture.

\section{Andante}

The Vitoria diocese had already appeared to be one of the most sensitive ones to the issue of building new churches in the post-war era. As early as 1947, it issued a series of orientation guidelines for those responsible for the said buildings 22 .

The architect Javier Carvajal, during his Roman stay as grantee of the Spanish Fine Arts Academy, had met and spoken -with his passionate speech - with a young priest who stayed at the Spain College: "The project for the Vitoria parish is linked to the interest pushing many of the architects who completed our degrees in the late 40s and early 50s to think about the need for a deep renewal of architecture in general. We were based on
Uno de sus mayores aciertos parece ser, además de la original solución litúrgico-funcional, el tratamiento de la luz, resuelto con la ayuda de José María Labra mediante vidrieras de color cambiante según su posición relativa con el presbiterio: más frío - azul — en la distancia, cambiante a tonos más encendidos - dorados - llegando sobre el altar. Encima del mismo se plantea un lucernario de luz natural — blanca - que provoca una tensión luminosa, para lo que Fisac se destaca como un auténtico maestro. Resulta llamativa la semejanza del efecto perseguido sobre el altar de Alcobendas con lo que Saarinen proyectó y ejecutó en 1957 para el presbiterio de la capilla del Instituto Tecnológico de Massachussets, en Cambridge (Estados Unidos), en lo que manifiesta - más que una improbable influencia, dada la contemporaneidad de las soluciones y la distancia geográfica - una analogía de sensibilidades. En el caso que nos ocupa, unos cables de acero descienden sobre el altar sirviendo de soporte a un gran crucificado de Pablo Serrano, que de esta manera queda como suspendido en el aire, a medio camino entre el cielo y la tierra, mediador perfecto transido por la luz de la gracia. Este mecanismo de presentación de la cruz, en la práctica como única imagen rodeando el altar, fue adoptada por su autor como paradigma, repetido con frecuencia en los sucesivos proyectos de espacios sagrados ${ }^{20}$.

En el fondo de la nave, tras el coro, se encuentra una vidriera realizada según cartones de Adolfo Winternitz, de gran presencia en el conjunto, que el arquitecto desautorizaba ${ }^{21}$. Aquella nunca provoca deslumbramiento, pues el lucernario de luz blanca sobre el presbiterio induce una luminosidad siempre superior a la del fondo. Las escenas simbolizan el martirio de San Pedro de Verona, primer mártir dominico y titular del conjunto, y su dramatismo resulta un buen complemento del ambiente general del templo. A pesar de la mencionada desaprobación del arquitecto, esta vidriera junto al resto de colaboraciones artísticas también resulta una excelente muestra de los derroteros figurativos del arte sacro de la época, e indudablemente colabora a la conformación de un conjunto ejemplar que, en la historia de la refundación moderna de la arquitectura española, señala un punto de inflexión.

\section{ANDANTE}

La diócesis de Vitoria ya se había señalado como una de las más sensibles al problema de la edificación de nuevos templos en la posguerra, dictando, en una fecha tan temprana como 1947, unas normas orientativas para los responsables de dichas edificaciones ${ }^{22}$.

En su estancia romana, becado en la Academia Española de Bellas Artes, el arquitecto Javier Carvajal había conocido y tratado — con su apasionado discurso - a un joven sacerdote, residente en el Colegio de España: «El proyecto de la parroquia de Vitoria, enlaza con el interés que animó a muchos de los arquitectos - que terminamos la carrera a finales de los años cuarenta y comienzo de los cincuenta - a plantearnos la necesidad de una renovación profunda de la arquitectura en general, apoyándonos en el Movimiento Moderno de anteguerra, enlazando con una actitud renovadora de todo el 
amplio marco de todas las artes y también del diseño industrial, interés que, tal vez, marcó nuestra vocación de arquitectos.

»Allí están, para siempre, los nombre precursores de Blanco Soler; de Coderch; de Alejandro de la Sota; Asís Cabrero; Aburto; Fisac y Sáenz de Oíza, maestros, algunos casi de nuestra misma edad, y los de la nueva generación de Molezún, Corrales, Paredes, yo mismo y tantos otros; con Bohigas; Correa; Milá; Moragas y el acompañamiento de prometedores nombres de Barcelona; y otros lugares de España que harían ese recuento abrumador (...).

»Armado con todas estas armas, y animado de todas estas certezas llegué a la Academia de España en Roma, y conocí en esa maravillosa ciudad, en el Colegio de España, a un sacerdote que fue objeto de mi catequesis arquitectónica renovadora, y que con el tiempo llegó a obispo de Vitoria mientras yo seguía siendo un arquitecto entusiasta. Y que cuando se hizo cargo de su diócesis, se acordó del arquitecto catequista para encargarle los proyectos de cinco nuevas parroquias, que a mí me parecieron muchas, pero pocas para mis deseos de renovación arquitectónica, por lo cuál le propuse los nombres de cinco arquitectos para dar forma a su deseo: García de Paredes, Molezún, Corrales, Fisac, Sota y yo mismo.

»Pero como no había dinero para abordar simultáneamente las cinco parroquias, y como no todos los arquitectos quisieron trabajar emparejados, los encargos se formalizaron tan solo en cuatro proyectos, de los cuales sólo dos, llegaron a construirse: el de Fisac y el nuestro.

»Porque, además, el obispo tuvo que sucumbir ante el rechazo de los párrocos y los parroquianos frente a la arquitectura nueva que se les ofrecía. Sin duda esas propuestas — concluye Carvajal - llegaron antes de tiempo» ${ }^{23}$.

Como señala el arquitecto catalán, con el tiempo, el joven sacerdote que conoció en Roma alcanzó la mitra episcopal; su nombre, Francisco Peralta Ballabriga ${ }^{24}$. La diócesis tenía su sede en la ciudad de Vitoria, población en crecimiento y, en consecuencia, necesitada de la correspondiente nueva dotación parroquial. El obispo volvió a contactar con su vehemente amigo arquitecto para encargarle cinco conjuntos parroquiales.

Carvajal — generoso e inteligente, y bien asesorado por el dominico José Manuel Aguilar, animador de la anhelada modernización- propuso repartir los encargos entre los mejores arquitectos de su generación. De esta manera Vitoria iba a contar con un muestrario de las mejores arquitecturas renovadoras, constituyéndose así en modelo para otras diócesis españolas. Se formaron los equipos, atendiendo a asociaciones profesionales anteriores o a afinidades personales: Fisac y Sota; Corrales y Molezún; Sáenz de Oíza y Romany; y el mismo Carvajal, en compañía de su amigo y compañero en la Academia de Roma, García de Paredes. Las dificultades de la empresa - económicas y de comprensión - motivaron que sólo dos conjuntos llegaran a edificarse: el de Fisac, quien compitió amistosamente con Alejandro de la Sota, su compañero de equipo - incapaces de armonizar un proyecto común-y el de Carvajal y García de Paredes. Fueron las parroquias de la Coronación de Nuestra Señora y de Nuestra Señora de los Ángeles.

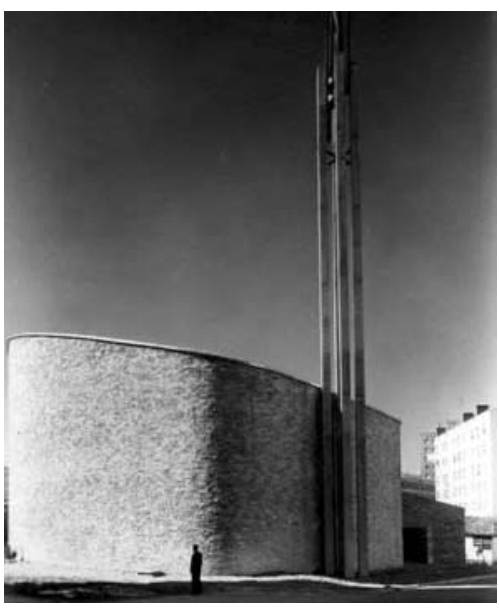

Iglesia parroquial de la Coronación de Nuestra Señora. Vitoria (1957/60)

the pre-war Modern Movement, linked to an innovative attitude within the framework of arts and industrial design. It may well be that this interest had marked our vocation as architects. »The pioneer names of Blanco Soler, Coderch, Alejandro de la Sota, Asís Cabrero, Aburto, Fisac and Sáenz de Oiza remain there. Some of the masters were of our same age, and those from the new generation of Molezun, Corrales, Paredes, myself and many others; with Bohigas, Correa, Milá, Moragas and accompanied by promising names from Barcelona and other places in Spain that would be too many to quote (...).

"Armed with all these weapons and encouraged by all those certainties, I reached the Spanish Academy in Rome and, in that wonderful city, I met at the College of Spain a priest who received my innovative architectural catechesis and who later would become the Bishop of Vitoria, while $I$ remained an enthusiastic architect. When he took charge of his diocese, he remembered the catechist architect in order to assign to him the projects for 5 new churches. I thought they were too many, though too few for my wishes of architectural renewal, so I suggested to him the names of 5 architects so as to shape his desire: Garcia de Paredes, Molezún, Corrales, Fisac, Sota and myself.

"But there was not enough money to tackle the 5 parishes at once, and not all the architects wanted to work in pairs, so only 4 projects were formalised, out of which, only two were finally built: Fisac's and ours. 


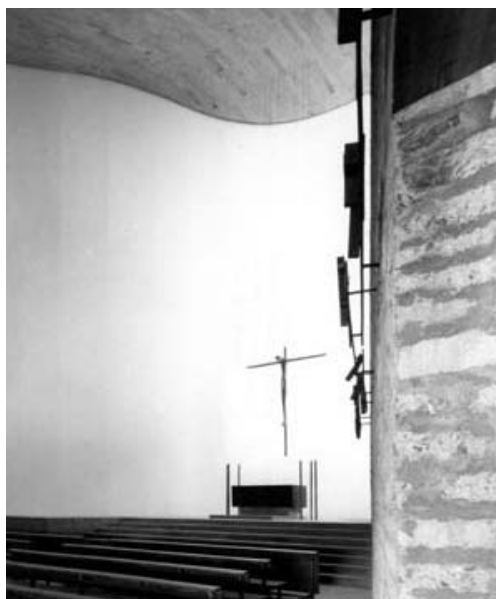

Iglesia parroquial de la Coronación de Nuestra Señora. Vitoria (1957/60).

"Moreover, the bishop had to give up before the parish priest's and the parishioners' rejection of the new architecture offered. Undoubtedly, those proposals arrived too early», ends Carvajal ${ }^{23}$. According to the Catalonian architect, the young priest he met in Rome would achieve the episcopal mitre; his name was Francisco Peralta Ballabriga ${ }^{24}$. The diocese was based in Vitoria, with a growing population who required the corresponding number of parishes. The bishop once again contacted his architect friend in order to assign 5 parish facilities to him.

Carvajal, who was generous and smart, and also well advised by the Dominican José Manuel Aguilar, encouraging the much-desired modernisation, suggested that the assignments should be distributed among the best architects in their generation. Thus, Vitoria would have a showcase of the best innovative architecture and would become a role-model for other Spanish dioceses. The teams were made according to previous professional associations or personal affinities: Fisac \& Sota; Corrales \& Molezún; Sáenz de Oíza \& Romany; and Carvajal himself, together with his friend and classmate at the Rome Academy, Garcia de Paredes. The financial and understanding difficulties of the enterprise caused that only two facilities were built: Fisac's, who established a friendly competition with Alejandro de la Sota, his team-mate - being unable to put together a joint project- and the team integrated by Carvajal \& Garcia de Paredes. The parishes built were those of Our Lady's Crowning and Our Lady of Angels.
Por su interés modélico reproduzco a continuación algunas de las intenciones del obispo Peralta Ballabriga, señaladas en la introducción a la correspondiente Sesión de Crítica de Arquitectura organizada en Madrid por Carlos de Miguel, a la que acudió personalmente el prelado:

«Condiciones que pone el cliente: la primera es la modernidad, entiéndase bien, no el modernismo banal y a la moda, sino actualidad de los proyectos. Esta fue una condición decididamente buscada. La Vitoria nueva, creación y resultado de una época, debe acoger unas parroquias en las que ya, inicialmente se rinda a Dios el homenaje del arte de nuestro tiempo, el testimonio de una época, en frase del Cardenal Lercaro ${ }^{25}$.

»En segundo lugar el templo de hoy debe responder a las exigencias de la vida religiosa moderna, informada por la Teología del Cuerpo Místico. Es decir la iglesia tiene que responder a este funcionalismo litúrgico que exige el espacio amplio y libre para que todos sean actores de la acción religiosa, que los fieles no se queden emboscados en la penumbra, como meros espectadores que no toman parte ni tienen interés en lo que allí acontece.

»Hay que recrear la perdida vida en comunidad de los fieles. Y a conseguir esto ha de ayudar en gran medida la acertada disposición del ámbito de la iglesia, de la ordenación de los edificios parroquiales y de los espacios libres que enlazan entre sí y aíslan del exterior el conjunto parroquial. Hay que buscar con estas nuevas parroquias el que el hombre no se pierda ni se distraiga, sino que entre, con todos sus hermanos, en la vida de la comunidad.

»Finalmente, estos edificios deben ser austeros y sinceros. Austeros como corresponde a la fe católica y que tan bien se acompasa con nuestras posibilidades económicas, y sinceros, llenos de autenticidad, en la expresión de la verdad religiosa servida por el arte al hombre moderno.

»Para desarrollar estos planos, y como primer esbozo, ofrecimos varios solares, ciertamente no exentos de dificultades, pero son los que se han podido poner al alcance de nuestras posibilidades» ${ }^{26}$.

Como se ha señalado, en 1957 y ante la solicitud del Obispo de Vitoria, Javier Carvajal y el padre Aguilar coordinaron la formación de los equipos de arquitectos atendiendo a una afinidad profesional o - en su defecto- personal. Evidentemente, este último es el caso de la pareja formada por Miguel Fisac y Alejandro de la Sota. Compañeros de preparación para el ingreso en la carrera de arquitectura, coincidieron también durante la guerra en las aulas de la Escuela de Arquitectura de Madrid, entonces en la calle de Estudios, y también a la vuelta a las aulas, ya en la nueva Escuela de la Ciudad Universitaria. En una conversación personal, Miguel Fisac me refería las emocionadas visitas del entonces joven arquitecto gallego a las obras de la capilla del CSIC en 1942/43, recién terminados sus estudios. Finalmente, en este apresurado repaso de las afinidades de los dos arquitectos, Sota reconocía la influencia de las investigaciones espaciales de Fisac, en su proyecto de iglesia parroquial para el poblado de Esquivel ${ }^{27}$.

En 1957 y con estos precedentes, ambos arquitectos conformaron uno de los equipos encargados de la elaboración de las nuevas parroquias 
necesitadas por la diócesis de Vitoria. No obstante todas las señaladas afinidades, además de su amistad —o puede que precisamente por ellaacordaron preparar cada uno un anteproyecto, dejando a la propiedad la libertad de elección ${ }^{28}$. En esta decisión también debió de influir la fuerte personalidad de los dos arquitectos, precisamente por ello, desacostumbrados a trabajar asociadamente.

Del ejercicio de Fisac cabe señalar que su anteproyecto se inserta en una serie que - como hemos visto - arranca en 1951, y en la que el arquitecto manchego exploraba estrategias para la captación de la atención de los fieles hacia el presbiterio. Precisamente, la explicación dada por Fisac en esta ocasión no deja lugar a dudas respecto a su intención: «esencial característica ha de ser la de conseguir un ambiente de espiritualidad; una iglesia ha de ser un trozo de aire sagrado que ayude plásticamente, sensorialmente, a los fieles a acercarse a Dios.

»Para conseguir este acercamiento de los fieles hacia Dios y crear un ambiente de comunión en la asistencia al Santo Sacrificio de la Misa se ha intentado conseguir un cierto dinamismo plástico hacia el altar. Este dinamismo está encomendado a dos factores: uno es la conjunción de un muro envolvente ('muro dinámico'), blanco, liso, sin ningún punto de referencia que obligue a la mirada a resbalar tangencialmente al fondo del ábside, donde se sitúa el altar, contraponiendo un muro de sillarejo visto ('muro estático'), más bajo, con una iluminación en celosía, y en el que se colocan una imagen de la Virgen, el Vía Crucis, la capilla del Santísimo Sacramento y la comunicación al baptisterio. De la conjunción de estas disposiciones paramentales se pretende conseguir ese dinamismo espacial. De otra parte, la fuerte iluminación del ábside, conseguida por un gran ventanal no visible directamente por los fieles; la ordenación cromática en fuga de las celosías del muro de piedra, unido a una disposición ascendente de techo y suelo, son los medios que se utilizan para conseguir esa tensión concentrada en el altar» ${ }^{29}$.

En el anteproyecto para Vitoria, Fisac concedía un cierto protagonismo a los espacios exteriores del conjunto, como necesaria extensión de la vida religiosa y comunitaria concentrada por la parroquia: «Como el trazado urbanístico de esta zona no había previsto, como era elemental haberlo hecho, un emplazamiento singular para la iglesia, se ha tenido que crear, formando una plaza que rompa la monótona alineación existente y de expansión y dignidad al emplazamiento de la iglesia» ${ }^{30}$.

Finalmente, siguiendo con los exteriores del templo, señalaba el arquitecto manchego, que «se ha creído indispensable para remarcar el sentido religioso del conjunto y destacarlo sobre la altura media de las edificaciones circundantes, la construcción de una sencilla torre de hormigón armado de características actuales» ${ }^{31}$. En esta intención figurativa moderna, Fisac ya se había destacado en Alcobendas, si bien otros autores como Sáenz de Oíza o Fernández Alba habían ido —o irían- más allá, en un camino opuesto, al proponer la supresión de la torre-campanario en sus ejercicios de carácter sacro, rompiendo así una tradición multisecular,
I will now quote some of the intentions of Bishop Peralta Ballabriga, due to their exemplary interest. They were expressed during the introduction to the already mentioned Session of Architecture Critique organised in Madrid by Carlos de Miguel, which the prelate personally attended:

"Here are the requirements set by the client: the first one is modernity, let me explain, not a banal hip modernism, but that the projects are up-todate. We definitely searched for that requirement. The new Vitoria is the creation and result of an epoch and it must welcome these parishes where God is praised by means of our contemporary art, by the testimony of an era, according to Cardinal Lercaro» ${ }^{25}$.

«Secondly, today's temple must answer the requirements of modern religious life which is informed by the Theology of the Mystical Body. That is, the church must respond to that liturgical functionalism demanding a wide free space so that everybody is an actor in the religious action, so that the faithful are not hidden in murkiness, as mere spectators who take no part or have no interest in what is going on there.

$»$ We need to recreate the lost community life of the faithful. The right arrangement of the church will help us to do it to a great extent, as well as the arrangement of the parish buildings and the free spaces linking and isolating the parish facility from the outside. These new parishes must help people not to get distracted but to live in the community, together with all their brothers and sisters.

»Finally, these buildings must be austere and sincere. Austere since it corresponds to the Catholic faith and it also fits our financial resources. Sincere, full of authenticity, expressing the religious truth served by art to modern persons.

"In order to develop these plans, we provided several plots as first drafts. They certainly faced some difficulties but they were those we had at hand» ${ }^{26}$.

As it was pointed out, in 1957 and at the Bishop of Vitoria's research, Javier Carvajal and Father Aguilar coordinated the training of the architect teams according to a professional or -in case there wasn't any- personal affinity. Obviously, the latter was the case of the pair integrated by Miguel Fisac \& Alejandro de la Sota. They prepared together the access to the Architecture faculty and also coincided during the war in the lecture halls of the Madrid School of Architecture, which was then at the Estudios Street, and also when they returned to lectures at the new School in the University City. Miguel Fisac told me during 
a personal conversation about the thrilled visits paid by the young Galician architect to the works of the CSIC chapel in 1942/43, having recently graduated. Finally, in this quick review of affinities between both architects, Sota acknowledged the influence of Fisac's spatial research on his parish church project for the village of Esquivel ${ }^{27}$.

In 1957 and with this background, both architects integrated one of the teams in charge of building the new parishes required by the Vitoria diocese. In spite of the already mentioned affinities, apart from their friendship, or maybe because of it, each of them decided to prepare a draft project, allowing the owners the choice ${ }^{28}$. The strong personalities of both architects probably influenced this decision, precisely because they were not used to work in an association.

From Fisac's exercise it may be said that his draft project is part of a series which started in 1951 in which the architect from La Mancha explored some strategies for catching the believers attention towards the presbytery. Precisely, Fisac's explanation in this occasion leaves no doubt as to his intention: "achieving an atmosphere of spirituality must be an essential characteristic; a church has to be a piece of sacred air which helps the faithful, both plastically and sensually, to get closer to God.

»In order to help the faithful to get closer to God and to create an atmosphere of communion when attending the Holy Sacrifice of Mass, we have attempted to achieve a certain plastic dynamics towards the altar. This dynamics is achieved by two factors: one is the presence of a wrapping wall (dynamic wall), a white flat wall with no reference point forcing the glance to slide tangentially to the back of the apse where the altar is located; the other is a lower exposed cut stone wall (static wall), with lattice lighting where a sculpture of the Virgin, the Way of the Cross, the chapel of the Holy Sacrament and the connection with the baptistery are. We aim at achieving that spatial dynamics with these paraments arrangements. On the other hand, the strong lighting on the apse is achieved thanks to a huge window not directly seen by the faithful; the increasing chromatic order of the stone wall lattices, all this linked to an upwards arrangement of roof and floor, are the means used so as to focus an increasing tension on the altar» ${ }^{29}$.

In the draft project for Vitoria, Fisac allowed a certain protagonist role to the outdoors of the precinct, seen as a necessary expansion of the religious and community life concentrated in the parish: «Since the urban planners had not foreseen - as it would have been natural to do- a specific place for the church, we have had to create a square breaking the already existing pero mostrando sin embargo una cuidadosa atención a las exigencias funcionales reales de nuestro tiempo.

Como es sabido, entre este anteproyecto y la realidad construida de la parroquia de la Coronación de Nuestra Señora hubo una cierta evolución, más formal que conceptual. En cualquier caso, el edificio se convirtió en uno de los mejores ejemplos de la llamada corriente orgánica en nuestro país y en su ejecución - según su costumbre- Fisac supo rodearse de excelentes artistas colaboradores, lo que en la práctica garantizaba una excelente ambientación interior ${ }^{32}$.

Pocos meses después, ya en 1959, el entonces obispo titular de la diócesis de Cuenca, Inocencio Rodríguez Díez, convocó un concurso para la edificación de una nueva parroquia en esa capital castellana. Pese al gran esfuerzo de los concursantes - muchos de ellos arquitectos que participaban de la inquietud del momento por la renovación litúrgica, y conscientes del atractivo del proyecto-, el concurso puede considerarse una oportunidad fallida. Fallida, por la adjudicación de premios y por la falta de criterio demostrada en esa adjudicación; fallida, por el descontento de gran parte de los concursantes, y fallida, en definitiva —y sin duda es lo más importante-, por el resultado construido.

La particular capacidad de Miguel Fisac para quemar sus naves a pesar de los éxitos cosechados, generó un nuevo giro de su obra en este concurso conquense, a la larga el más definitivo, el más radical. En efecto, la preocupación del arquitecto por las posibilidades expresivas del material iban a embarcar a Fisac en una nueva aventura. Se trata de una exploración que acabaría aislándole de los derroteros más comunes del resto de la profesión en un camino personalísimo, con frecuencia poco comprendido por sus iguales, los arquitectos, y que, paradójicamente, le encumbraría en la escala social como el arquitecto más moderno de su generación: la expresividad del hormigón y los prefabricados con este material.

Fisac volvía a inventar. En la década de los cincuenta había sido la patente del ladrillo para cerramientos ligeros; ahora eran los huesos, los encofrados flexibles y todo aquello que contribuyese a manifestar el proceso de elaboración y puesta en obra del material. Fisac optaba decididamente por el hormigón en una elección de carácter casi ético. Preocupado por la expresión de los materiales, el hormigón era el que — siempre según el arquitecto- mayores posibilidades presentaba y, no obstante, menor desarrollo había tenido. De aquí en adelante Fisac se empeñaría en esta batalla, condenado a una carrera en solitario; su vehemente forma de ser y la fidelidad a sus principios - a una ética de la construcción- parecía anunciarlo ya desde sus primeros proyectos.

Así, en el concurso de Cuenca, Fisac rompía con sus investigaciones espaciales anteriores centradas en la teoría del muro dinámico para adentrase en una exploración de carácter estructural y constructivo. El propio arquitecto lo explicaba como sigue: «He de confesar que en aquella época - mediados de los años cincuenta - estaba tan obsesionado con la importancia del espacio interior y la veracidad de la calidad expresiva 
de los materiales, que dejé bastante olvidado el aspecto exterior de los edificios, la valoración de sus volúmenes exteriores, y también los medios estructurales con los que se conseguían esos espacios.

$» \mathrm{Me}$ di al fin cuenta de esos olvidos y deficiencias, y un cariñoso reproche, en 1958, de mi amigo y compañero Fernando Casinello, sobre mi despreocupación por la investigación estructural en mis proyectos, me hizo reconsiderar la cuestión y, en la primera ocasión que se me presentó, en el concurso nacional para la construcción de la parroquia de San Esteban en Cuenca, realicé un estudio de estructura de cubierta con piezas de membrana de hormigón de doble curvatura, que aunque no era de una gran novedad técnica, sí era adecuada para mi propósito» ${ }^{33}$.

Probablemente ningún arquitecto español presentaba un historial, una experiencia y una fama tan ganada como Fisac en estas lides. Sin embargo - muy en su estilo - tiraba todo por la borda planteando un proyecto único, original e incomparable. Bajo el lema «Gaviota» proponía un espacio conformado en planta por un sector circular de $90^{\circ}$ y una cubierta de conchas autoportantes prefabricadas en hormigón, cuya sección evocaba lejanamente el perfil alado de aquella ave. Aquí se recogían — trascendiéndolas - las experiencias de Alcobendas y de Vitoria en una singular síntesis. Con todo, la despreocupación por la presencia urbana o tal vez, precisamente, una apuesta por la rotura de la pobre escala circundante, iba a ser lo que le privase del primer premio, algo que Fisac lamentaría largamente pese a tener — casi inmediatamente — la oportunidad de construir una variante de su propuesta en la Escuela de Misioneros del Espíritu Santo en Calahorra. Se trataba de un lujo por entonces sólo al alcance de este arquitecto.

\section{ALLEGRO}

El 25 de enero de 1959, fiesta de la conversión de San Pablo y día de clausura del octavario por la unidad de los cristianos, al final de una ceremonia en la basílica romana de San Pablo Extramuros, el Papa Juan XXIII comunicó a los cardenales presentes en aquel acto su designio de convocar un concilio, el XXI de los ecuménicos. Los objetivos del mismo habían sido ya esbozados en la encíclica "Ad Petri Cathedram», primera del pontificado de Juan XXIII: promover el incremento de la fe católica y una saludable renovación de las costumbres del pueblo cristiano y adaptar la disciplina eclesiástica a las condiciones de nuestro tiempo.

Lo cierto es que en el orden litúrgico el Concilio venía a recoger una importante corriente de renovación que pretendía un acercamiento de los misterios de la Iglesia al pueblo fiel. Este espíritu fue el alma de la constitución «Sacrosanctum Concilium». En efecto, en este documento se contiene el germen de las reformas realizadas desde entonces en el espacio sacro, probablemente las más importantes en los veinte siglos de historia de la Iglesia.

Sentados los principios teóricos de la renovación, incumbía entonces a arquitectos y artistas, en estrecha colaboración con las autoridades competentes, transformar en propuestas construidas el nuevo espíritu. monotone alignment and providing the church with expansion and dignity" ${ }^{30}$.

Finally, going on about the outdoors of the temple, the architect from La Mancha said that «a simple armoured concrete tower with modern characteristics had to be built, in order to reinforce the religious sense of the precinct and to make it stand out above the average height of the surrounding buildings» ${ }^{31}$. Fisac had already stood out in Alcobendas with this modern figurative intention, whereas other authors, such as Sáenz de Oiza or Fernández Alba had gone or would go along the opposite direction, suggesting that the belfry should be discarded in their sacred buildings. This broke with a tradition of thousands of centuries, but it also showed a careful attention to the actual functional requirements of our times.

It is well known that, between this project and the reality of the construction of the parish of Our Lady's Crowning, there was a certain evolution, though more formal than conceptual. Anyhow, the building became one of the best examples of the so-called Spanish organic trend. As usually, Fisac managed to surround himself with excellent collaborating artists, which in practice guaranteed an excellent interior atmosphere $^{32}$.

A few months later, in 1959, the Bishop in office of the Cuenca diocese, Inocencio Rodríguez Diez, called a tender for building a new parish in the Castilian city. In spite of the great efforts made by the contestants, many of whom were architects sharing the interest of those times for liturgical renewal, and who were aware of the appeal of the project, the contest was a failed chance. It was failed due to the prizes awarded and due to the lack of criterion shown; it was failed due to the discontent of a great part of the contestants, and it was finally failed due to the constructed result, which was certainly the most serious thing.

Miguel Fisac's particular capacity to burn his bridges in spite of the successes achieved gave his work another turn of the screw at the Cuenca contest. This turn would be the most final and radical one. Certainly, the architect's concern with the materials expressive capacities would lead him to a new adventure. This exploration would end up by isolating him from the trite paths of the remainder of his profession, leading him through a very personal path, often scarcely understood by his peers, but which, paradoxically, would send him up the social ladder as the most modern architect in his generation: the expressiveness of concrete and pre-fabs of the same material.

Fisac tried once again. In the 50s, he got a patent for his brick for light closings; now he came up 


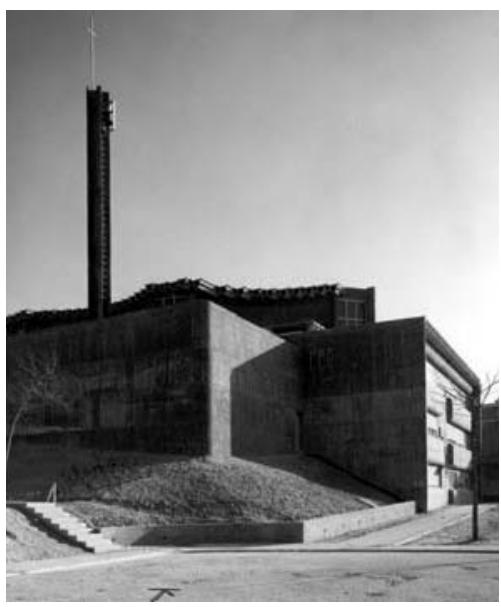

with bones, flexible shuttering and everything which contributed to show the manufacturing and placement of the material. Fisac firmly opted for concrete in an almost ethical decision. Concerned with the expression of materials, according to the architect, concrete was the one offering the most chances and, in spite of it, had been less developed. From then on, Fisac would be intent on his battle, acting as a long-distance runner; his vehement nature and his sticking with his principles — with an ethics for construction - announced this from the very beginning.

Thus, in the Cuenca contest, Fisac broke up with his previous spatial research focused on the dynamic wall theory, in order to start with a structural and constructive exploration. The architect explained it so: "I must confess that at that time, the mid 50s, I was so obsessed with the relevance of the interior space and the truthfulness of the materials expressive quality that I left behind the outer appearance of buildings, the evaluation of their outer volumes, as well as the structural means by which those spaces were reached.

"I realised at last about these forgetfulness and flaws, and a warm scolding by my friend and colleague Fernando Casinello in 1958, about my carelessness about structural research in my projects, led me to reconsider the issue. So, on the first occasion I had, at the national contest for building Saint Stephen's parish in Cuenca, I did a study of a structure covered with pieces of double curve concrete membrane. Though this was not a huge technical novelty, it was fit for my purposes» ${ }^{33}$.

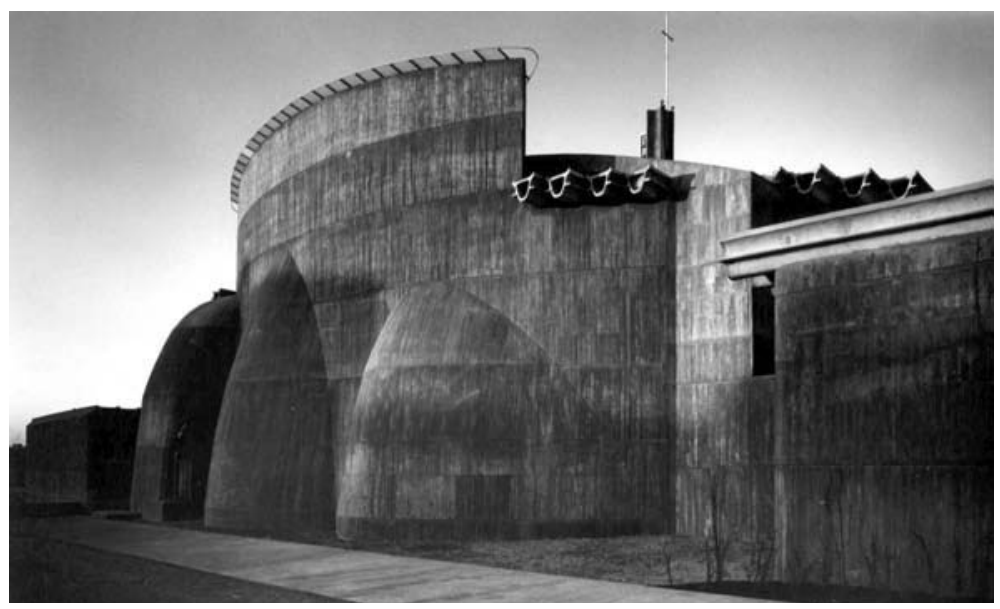

Iglesia parroquial de Santa Ana de Moratalaz, Madrid (1965/71).

Entre los arquitectos con experiencia y «furiosamente» ${ }^{34}$ en activo en aquellos años, pocos tan sensibles y preparados como Miguel Fisac para esta función de la reforma. Consciente de su responsabilidad e ilusionado con ella, el arquitecto manchego renovó su condición de protagonista de la arquitectura sacra española en estos primeros años del postconcilio.

La primera ocasión para esta labor tuvo lugar en el encargo de la iglesia parroquial dedicada a Santa Ana para uno de los polígonos del nuevo distrito de Moratalaz, en Madrid. El templo, con el que tanto Casimiro Morcillo — entonces arzobispo de Madrid-Alcalá- como la empresa constructora URBIS quisieron honrar la memoria de la entonces recientemente fallecida Anaick, hija del arquitecto, resultó una propuesta audaz, llena de vigor plástico y cargada de ilusionadas y renovadas intenciones litúrgico-funcionales: «Ésta es la primera iglesia que proyecté con las directrices litúrgicas emanadas del Concilio Vaticano II. El planteamiento espacial era completamente distinto, casi opuesto al de las disposiciones anteriores. No había un único foco, el altar, sino un foco móvil» ${ }^{35}$.

El planteamiento espacial al que se refiere Fisac tenía que ver con la nueva disposición de los fieles alrededor del altar para que la participación en las celebraciones litúrgicas fuese más directa. Para ello $-\mathrm{y}$ con un proceso discursivo análogo al seguido en Alcobendas- Fisac inventó la peculiar forma en planta de Santa Ana, concediendo mayor importancia al eje transversal de la planta. Asimismo, para completar su atractivo proyecto y subrayar el carácter litúrgico de su diseño, Fisac propuso tres concavidades en el muro curvo que cerraba el presbiterio, correspondientes a los diferentes momentos de la celebración litúrgica y a la propia reserva eucarística: la central para el altar, a su derecha el conjunto sede-ambón y a su izquierda el sagrario. 


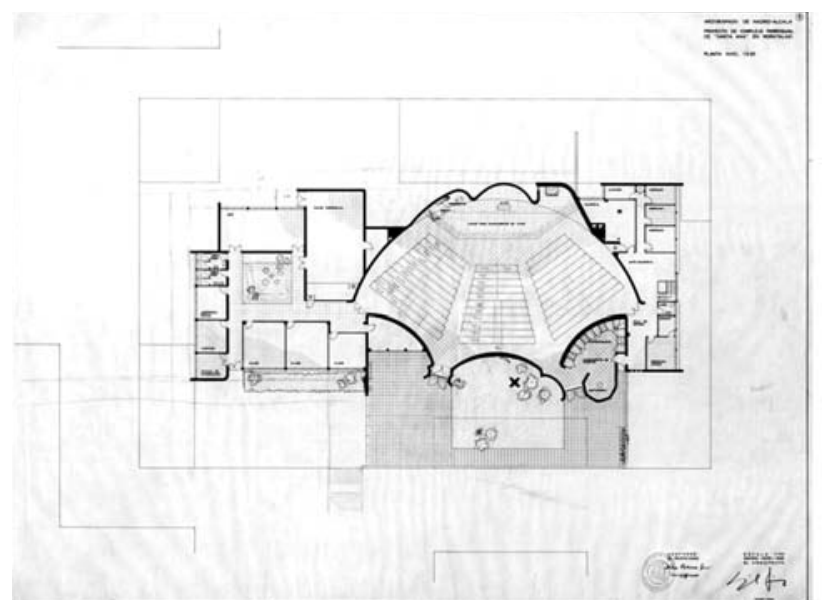

Iglesia parroquial de Santa Ana de Moratalaz, Madrid (1965/71).

El conjunto se culminaba con la inequívoca firma de su autor - expresión de sus crecientes preocupaciones en el terreno de lo estructuralconstructivo- mediante una cubierta de «huesos», vigas de hormigón prefabricado, dispuestas paralelamente a la línea de pies a cabecera del templo y que, precisamente sobre el presbiterio, se interrumpían antes de tocar el muro cabecero para bañar de luz esa zona del templo.

Indudablemente el complejo parroquial de Santa Ana se beneficiaba de las recientes investigaciones sobre las posibilidades expresivas del hormigón, en las que Fisac se encontraba inmerso en cuerpo y alma. Todo el conjunto se construyó con este material, dejando una lección verdaderamente magistral de originalidad, de oficio y de capacidad plástica.

El programa propuesto respondía a las nuevas necesidades -espaciales y pastorales-planteadas en la década de los sesenta, que venían a equilibrar las superficies destinadas al culto con otras que ampliaban lo que podríamos llamar el programa social de las parroquias. Igualmente, y como ya se ha señalado más arriba, el mismo programa cultual y celebrativo venía a matizarse con una orientación claramente más participativa, secundando un giro histórico en la concepción espacial del templo católico.

En el caso que nos ocupa, la disposición del programa se hizo atendiendo a la peculiar topografía del solar, reservando la parte más alta y, por lo tanto, con posibilidades de mayor presencia en el barrio para el templo propiamente dicho, rodeando su volumen con las dependencias pastorales de previsible mayor tránsito ciudadano. Para ello, el arquitecto proyectó una compleja macla de dos familias geométricas de difícil casamiento: una primera de generación cónica — una suerte de traza parabólica que procuraba la mayor participación posible de la asamblea alrededor de los misterios de la celebración y sobre la que volveremos más adelante- y otra más convencional de tipo ortogonal. Así, a un lado y otro del templo
There was probably no other Spanish architect who presented such a résumé, such an experience in the field and such a fame as Fisac. Nevertheless, very much in his style, he would throw everything overboard by putting forward a single and original project without comparison. Under the title Gaviota (Seagull), he proposed a space integrated by a $90^{\circ}$ circular sector and a cover made of selfsupporting shells in pre-fabricated concrete which section vaguely recalled the bird's winged profile. The Alcobendas and Vitoria experiences were compiled there in a singular synthesis. Anyway, the carelessness about the urban presence or, maybe, an intentional attempt to break with the poor surrounding scale, robbed him of the first prize. Fisac regretted it deeply, though he almost immediately got the chance to build a variant of his proposal at the Calahorra School of Missionaries of the Holy Ghost. This was a luxury which only this architect could afford.

\section{Allegro}

On 25 January 1959, celebrating Saint Paul's conversion and closing day of the octave by the Christian community, at the end of a ceremony at the Roman basilica of Saint Peter Extramural, Pope John XXIII informed those cardinals present of his wish to call a council, the 21st of the ecumenical ones. Its goals had already been drafted in the encyclical "Ad Petri Cathedram», the first one in John XXIII's pontificate: promoting the expansion of the Catholic faith and a healthy renewal of the Christian people's costumes, adapting the church discipline to our time's conditions.

The truth is that, at liturgical level, the Council would portray a considerable renovation trend which intended to get the mysteries of the Church to the faithful. This spirit was the soul of the constitution «Sacrosanctum Concilium». In fact, this document contains the germ of the reforms introduced since then in sacred spaces, which were probably the most important ones in the 20 centuries of the Church's history.

Having set the theoretical principles of renovation, it was the turn of architects and artists, in close collaboration with the competent authorities, to transform the new spirit into constructed proposals. Few of those architects were as sensitive and ready as Miguel Fisac for this reform, among those who were experienced and "furiously» ${ }^{34}$ active in those years. Well aware of his responsibility and thrilled with it, the architect from La Mancha renewed his protagonist status in Spanish sacred architecture in these first few post-council years.

The first chance for this task came with the assignment of the parish church devoted to 
Saint Anne, in one of the poles of the new Moratalaz district, in Madrid. The temple was meant to honour the memory of the late Anaick, the architect's daughter. Both Casimiro Morcillo, the Archbishop of Madrid-Alcalá, and the real-estate developers URBIS joined in the tribute. This was a daring proposal, one full of plastic vigour and full of illusion and renewed functional-liturgical intentions: "This was the first church I planned following the guidelines issued by the II Vatican Council. The spatial plan was totally different; it was almost the opposite from the previous arrangements. There was no single focus, the altar, but a mobile focus» ${ }^{35}$.

The spatial plan referred to by Fisac had to do with the believers' new arrangement around the altar, so that they had a more direct participation in liturgical celebrations. For that purpose, and following a discourse similar to the one followed in Alcobendas, Fisac invented the peculiar plan shape of Saint Anne which highlighted the transversal axis of the plan. Moreover, in order to complete his appealing project and to remark the liturgical nature of his design, Fisac put forward three concavities in the curved wall closing the presbytery, corresponding to three different moments in the liturgical celebration and to the Eucharist reserve itself: the central one for the altar, the see-pulpit set on the right and the tabernacle on the left.

The building was lit up with its author's undoubted signature - expressing his growing concern with constructive structure-: a cover of bones, i.e., pre-fabricated concrete beams running in parallel from the feet to the head of the temple and which stopped at the presbytery before touching the head wall, flooding with light that area of the temple. It is undoubted that Saint Anne's parish complex benefited from the recent research on the expressive possibilities of concrete to which Fisac had devoted body and soul. The whole building was made of this material and it constitutes a brilliant lesson in originality, professionalism and plastic capacity.

The programme put forward responded to the new spatial and pastoral requirements planned in the 60s. They tried to balance the areas devoted to worshipping with those which expanded the parishes social programme. As it has been mentioned, the same cult and celebration programme was polished with a more participative approach. This constituted a historical turn in the spatial conception of the Catholic temple.

In this instance, the programme arrangement was made paying attention to the peculiar plot topography. The highest part was reserved having the chance to stand out more conspicuously

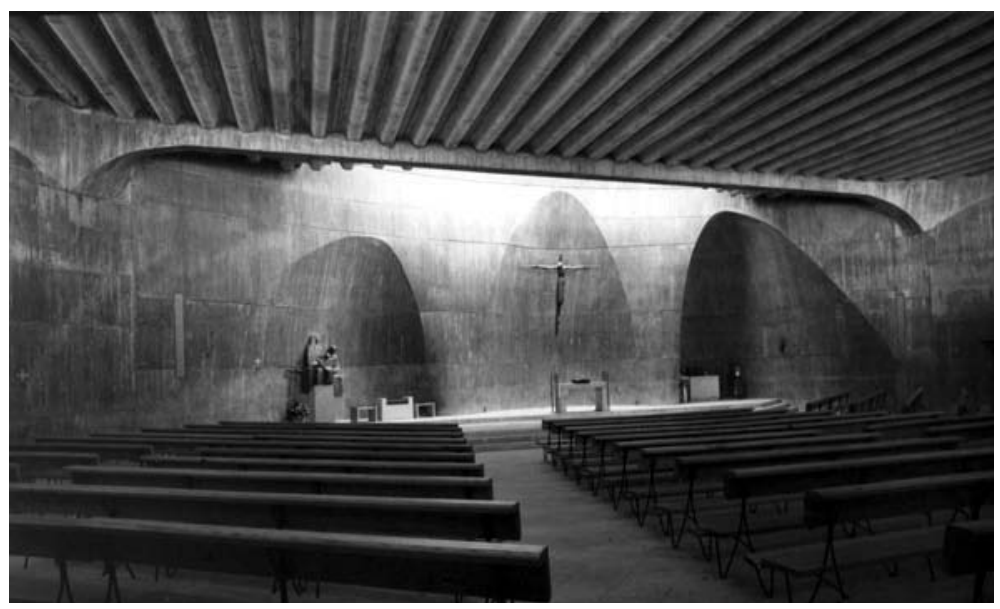

Iglesia parroquial de Santa Ana de Moratalaz, Madrid (1965/71).

propiamente dicho, se alinearon los espacios destinados a la atención pastoral. Vinculados a la vía principal y por lo tanto también al acceso, un primer cuerpo articulado alrededor de un pequeño patio, expediente habitual y muy querido en las arquitecturas de Miguel Fisac, que contenía una novedosa oficina de información parroquial, un despacho para Cáritas que, junto al despacho de asistencia social y unos aseos, conformaban la primera crujía de este conjunto. Un bar, el salón parroquial con acceso independiente desde el exterior y tres clases destinadas para catequesis, terminaban de definir este primer cuerpo del complejo.

Al otro lado del templo, y con una geometría también de tipo ortogonal, se ubicaba el programa parroquial no celebrativo: tres despachos, un pequeño almacén, despacho administrativo, archivo y aseos, además de la sacristía, vinculada a la cabecera del templo aunque con un acceso más retrasado - como a media altura de la nave - para, en un gesto muy de la época, favorecer la ascensión del celebrante desde la asamblea hacia el presbiterio. Completaban el programa de esta planta del complejo la antesacristía amplia y acogedora, y una sala de espera para los fieles. En esta misma zona y aprovechando el fuerte desnivel del terreno - de unos siete metros aproximadamente-, el arquitecto dispuso el programa residencial del complejo en dos plantas inferiores, que sirven para comunicar el plano del templo y del acceso principal con el más bajo y de carácter más doméstico.

Lo cierto es que esta configuración - el encuentro de dos familias geométricas distantes ${ }^{36}$, la primera de carácter convergente, asociada a la nave de los fieles, abrazada lateralmente por la segunda, mucho más ortogonal, que contiene el programa parroquial no celebrativo- podría rastrearse y se encuentra de hecho latente en el proyecto de la iglesia parroquial de Canfranc, que precisamente por su carácter rural y geográficamente apartado de los 


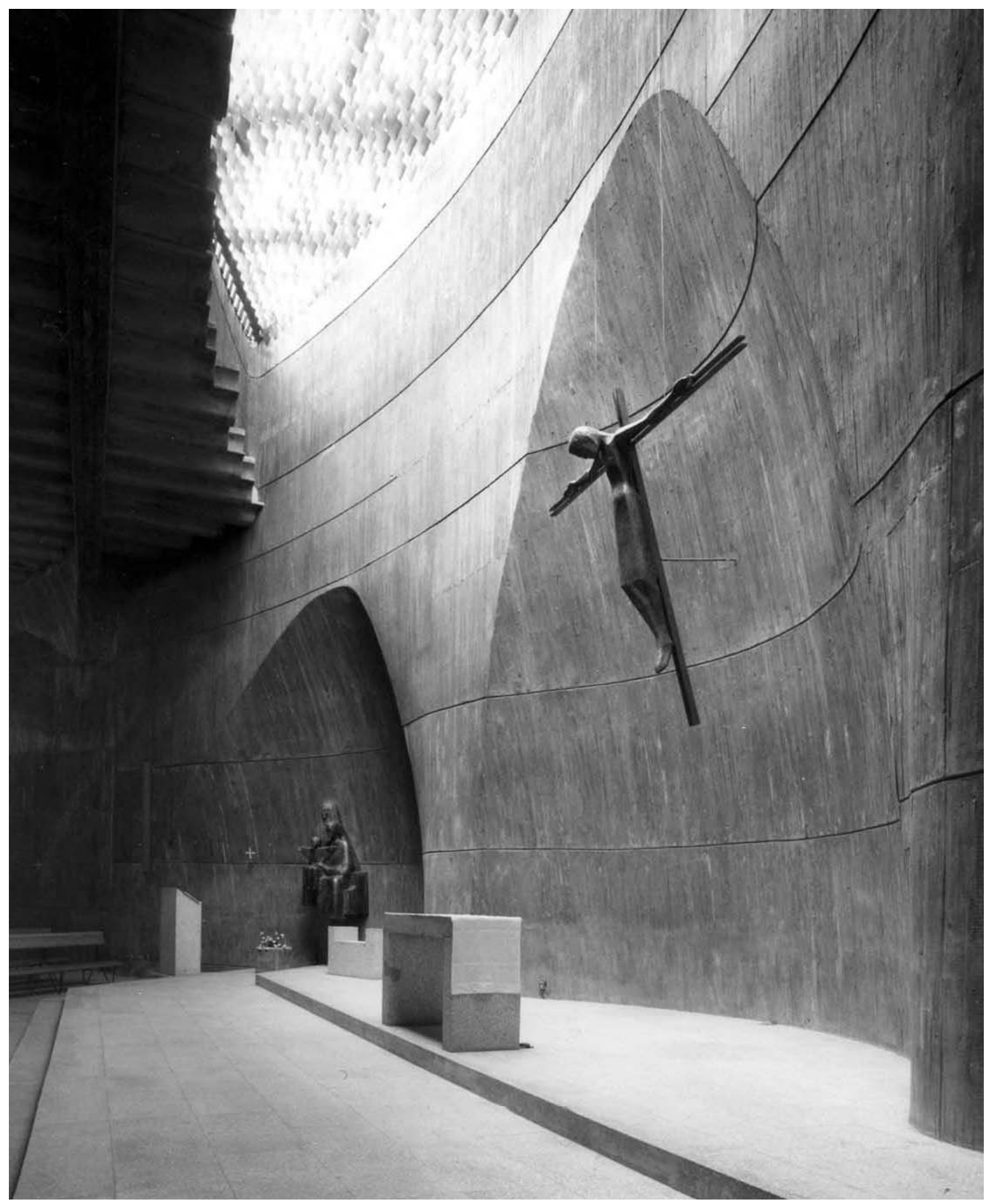

Iglesia parroquial de Santa Ana de Moratalaz, Madrid (1965/71). 
in the quarter-for the temple itself, and its volume was surrounded with the pastoral dwellings which would probably see a more intense human traffic. For this purpose, the architect projected a macle with two hard-fitting geometrical families: the first one was a conical shape - some sort of parable which intended to foster the assembly's participation in the mysteries of the celebration, and which will be discussed later- while the second one was more conventionally orthogonal. Thus, the spaces dedicated to pastoral attention were aligned at both sides of the temple. They were linked to the main way and also to the entrance. The first body was articulated around a small courtyard - a usual and well-loved system by Miguel Fisac - containing a brand new parish information office, another one for Cáritas, plus the social care office and some toilettes. These integrated the first row in the building. A bar, the parish hall with independent access from the outside and three classrooms for catechesis also defined the first body of the complex.

At the other side of the temple, and also with an orthogonal geometry, was the not-forcelebration parish programme: three offices, a small warehouse, a bureaucratic office and the sacristy linked to the head of the temple although with a further access - around halfway along the nave-in order to facilitate the celebrating priest's ascension from the assembly to the presbytery, a usual gesture of those times. There was also an ante-sacristy, wide and welcoming, as well as a waiting room for the believers in the same plan. In the same zone, making the most of the strong slope of the plot (approximately $7 \mathrm{~m}$ ), the architect arranged a residential programme of the complex in two lower storeys which serve to communicate the plan of the temple and the main access with the lower, domestic storey.

The truth is that in this configuration - the meeting of two distant geometrical families ${ }^{36}$ - the first one had a convergent nature and it was associated to the faithful's nave. The second one surrounded it at one side and it was much more orthogonal. It contained the parish programme not intended for celebrations and it could be traced back to Canfranc parish church where it was dormant. However, due to its rural nature and due to its geographical detachment from the main poles of architectural critique of the times, it was never sufficiently valued. Certainly, Fisac followed the insights shown at the Cuenca contest, and planned for the first time in this temple what could be defined as a transversal assembly space, as opposed to a more processional-longitudinal model. This pointed out brilliantly and quite early núcleos más importantes de la crítica arquitectónica de la época, no ha sido suficientemente valorado. En efecto, y secundando las intuiciones esbozadas en el concurso de Cuenca, en este templo Fisac planteaba por primera vez lo que podríamos apuntar como un espacio asambleario transversal, frente al modelo más procesional-longitudinal, señalando, en un entendimiento lúcido y precoz de las intenciones renovadoras del Concilio, el camino para las trazas de Santa Ana y otros ejercicios posteriores.

Volviendo al proyecto madrileño, en cuanto a su definición constructiva y siguiendo las que por entonces eran inquietudes poco menos que irrenunciables del arquitecto ${ }^{37}$, el proyecto se concibió en hormigón armado, si bien con una gran riqueza de soluciones, desde los prefabricados de los forjados o las cubiertas, a las fábricas «in situ» de los muros sustentantes. Esta riqueza constructiva, derivada de la voluntad de su autor por encontrar la mayor sinceridad y expresividad del hormigón armado, dotó de una presencia absolutamente original e irrepetible a este conjunto parroquial.

Fisac, arquitecto rabiosamente participante del proyecto moderno, acudía a parámetros experimentables empíricamente para explicar su arquitectura, sabiendo no obstante, que la calidad de cualquier arquitectura se relacionaba con aquel «no se qué» que él mismo llegó a enunciar en su célebre itinerario mental como componente ineludible de cualquier proceso proyectual. Así, temas como la acústica o la iluminación, en su dimensión aparentemente más prosaica, eran referencias habituales en su discurso arquitectónico ${ }^{38}$. No podía ser de otra manera en este proyecto de Santa Ana: «La acústica ha sido el elemento configurador en el aspecto del templo. La iluminación en las diferentes dependencias responde a las características más adecuadas para este tipo de recintos como despachos, aulas, salón de actos, bar, etcétera» ${ }^{39}$.

Pero si esto es así en todos los espacios del complejo, de un modo particularísimo lo es en la nave del templo. Santa Ana consigue apresar el espacio generado por la asamblea convocada a la celebración litúrgica. Un espacio congelado por una envolvente densa, opaca y oscura que se activa precisamente por sus discontinuidades, sus pliegues, sus incisiones, sus rasgaduras: «Se ha buscado una luz cenital suave en toda la zona del presbiterio y cuatro fajas verticales encima de las cuatro puertas de iluminación lateral de la nave. Para que estos ventanales respondan a las exigencias acústicas y de dispersión luminosa necesarias, estas vidrieras son de vidrio normal armado y una celosía de lamas metálicas de aluminio anodizado que forman una dispersión luminosa necesaria tanto en iluminación natural como artificial, y solamente coloreada por el anodizado en oro de la celosía de aluminio del presbiterio o por el anodizado en azul de las vidrieras situadas encima de las puertas de la nave ${ }^{40}$. En esta detallada descripción puede adivinarse la decantación de la experiencia del autor, tanto en la dimensión constructiva como de la propia ambientación del templo.

No obstante, podría apuntarse con Juan Plazaola —introductor y traductor del espíritu de la nueva liturgia en nuestro país - que «a esta iglesia 


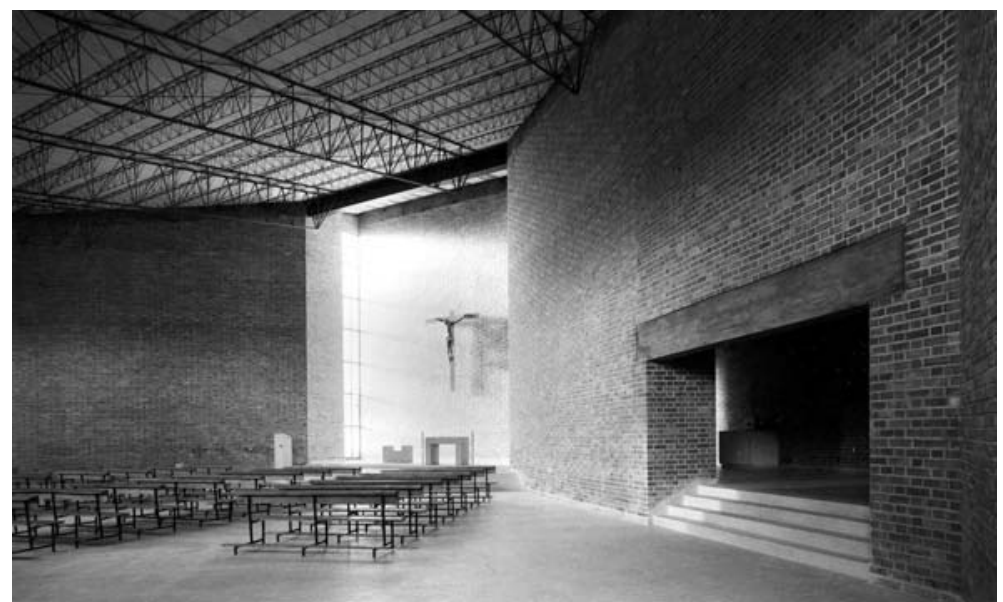

Iglesia parroquial de Santa María Magdalena, Madrid (1966/68).

le queda aún un cierto lastre de concepciones espaciales precedentes al observar la penumbra en la que deja a la comunidad» ${ }^{41}$. El mismo Plazaola explicaba a continuación que «la acción eucarística debiera ser una celebración festiva y jubilosa, y todo el espacio en que se asienta la comunidad y en el que se escucha, reza, lee, canta desfila y se mueve, debiera ser luminoso y alegre expresando la existencia y la vida de una comunidad transida por la vivencia de la Resurrección de Cristo» ${ }^{42}$. De hecho, esta concepción será recogida por Fisac — siempre sensible al espíritu de los tiempos - en algún ejercicio posterior, aunque hay que decir que de menor interés proyectual ${ }^{43}$.

En efecto, desde los primeros tiempos de la capilla del Espíritu Santo para el CSIC, Fisac se había mantenido fiel al llamado «género místico» - «los que concentran la atención de cada uno de los fieles en el altar, usando de los medios que proporciona la forma y la luz, de modo que éste resplandezca en contraste con la penumbra de la nave»- siguiendo la clasificación elaborada por Luis Moya con motivo del concurso de anteproyectos para la iglesia parroquial de San Esteban protomártir, en Cuenca ${ }^{44}$. De hecho, ya en aquella ocasión, Moya utilizaba la capilla del CSIC para ilustrar la descripción del género en cuestión, enmarcándolo en la tradición de muchas iglesias castellanas de nave muy oscura y techumbre baja, con presbiterio de bóvedas altas y grandes ventanales generalmente gótico, de las que suele decirse que este presbiterio fue el principio de una reconstrucción total de la iglesia que no llegó a realizarse. Ejemplar de este género sería la iglesia del Salvador en Úbeda, de Vandelvira; la capilla del Espíritu Santo para el CSIC de Fisac sería otro ejemplo nítido. Este género tendería a favorecer el recogimiento personal por encima de la participación; en él se hace más fácil estar en relación con Dios que con el prójimo. at the Council's innovative intentions, opening the way to Saint Anne's traces and to later exercises.

Returning to the Madrid project, with regard to its constructive definition and following the architect's almost unswayable interests ${ }^{37}$, the project was made of armoured concrete, though with a rich variety of solutions, ranging from the pre-fabricated forged pieces or covers to the on site manufacture of the supporting walls. This constructive variability, which derived from its author's will to find the greatest sincerity and expressivity of armoured concrete, gave this parish complex an absolutely original and unrepeatable presence.

Fisac was an architect who took a passionate part in the modern project. He empirically resorted to experimentable parameters in order to explain his architecture. He knew, nevertheless, that the quality of architecture is related to a certain something mentioned by him in his famous mental itinerary as a necessary element of any project process. Thus, topics such as acoustics or lighting, in their apparently more prosaic dimension, were usual references in his architectural discourse ${ }^{38}$. It could not be otherwise in Saint Anne's project: "Acoustics has been the defining element in the temple appearance. Lighting at the various areas responds to the fittest characteristics for these rooms, such as offices, classrooms, conference halls, bar, etc.». ${ }^{39}$

This is so at every space in the complex, but even more so at the temple nave. Saint Anne manages to capture the space created by the assembly of believers called to the liturgical celebration. A space frozen by an enveloping, dense, opaque and dark atmosphere which is activated precisely by its discontinuities, its folds, its incisions, its tears: «A mild zenithal light has been sought for the whole of the presbytery and the four vertical strips above the four doors in the nave with lateral lighting. These windows are made of normal armoured glass and a lattice made of anodised aluminium slats in order to respond to the acoustic and light dispersion requirements. They create the necessary light dispersion both with natural and artificial light, only tinted by the golden anodised material of the presbytery aluminium lattice or the blue anodised one from the windows above the doors of the nave» ${ }^{40}$. This detailed description shows the decantation of the author's experience, both in the constructive dimension and in the temple atmosphere.

Nevertheless, we could agree with Juan Plazaola -the presenter and translator of the spirit of 
the new liturgy in Spain — that «this church still suffers from the ballast of some previous spatial approaches, particularly when you see that the community has been left in murkiness» ${ }^{41}$. Plazaola explained next that «the Eucharist should be a festive and joyous celebration, and the whole community space, where they listen, pray, read, sing, parade and move, should be clear and cheerful, expressing the existence and the life of a community inspired by the experience of Christ's resurrection $\rangle^{42}$. In fact, this approach will be collected by Fisac - who was always sensitive to the spirit of the times-in a later exercise, although with a less interesting project ${ }^{43}$. Certainly, from the early times of the CSIC Holy Ghost chapel, Fisac had remained faithful to the so-called mystic genre: "those who focus each believer's attention on the altar, using the means provided by shape and light, so that it dazzles in contrast to the murkiness in the nave»; following Luis Moya's classification on the occasion of the contest for draft projects for Saint Stephen Protomartyr's parish church in Cuenca ${ }^{44}$. In fact, Moya used then the CSIC chapel to illustrate the description of the genre itself, framing it in the tradition of many Castilian churches with very dark nave and low ceiling, and with a tall-domed presbytery and huge (usually) Gothic stained-glass windows. It is usually said that this presbytery was the start of a total reconstruction of the churches that was never accomplished. Saint Saviour's church in Úbeda, by Vandelvira, would be an example of that genre; the CSIC Holy Ghost church by Fisac would be another clear example. This genre would favour personal devotion instead of participation; it becomes easier to relate to God than to your peers.

In this regard, the path followed by Miguel Fisac should be understood as a true ascetic exercise: the way from a relationship between the creatures and their el Creator based on fear and distance, to an understanding of their real divine descent, their familiarity and so their closeness to the same God. Nevertheless, this dimension, worth mentioning at this point, raises spiritual issues which go beyond the purposes of this paper. Saint Anne's plans should have been on Miguel Fisac's professional studio desk together with those belonging to projects of the same type: Saint Mary Magdalene's parish at Madrid Santamarca pole, Santa Cruz of Oleiros, A Coruña or the church project for the Dominican mission in Formosa, all of them informed by similar spatial criteria though each of them was touched by some specificity.

At a particularly fruitful period in the career of the architect from La Mancha, Fisac received

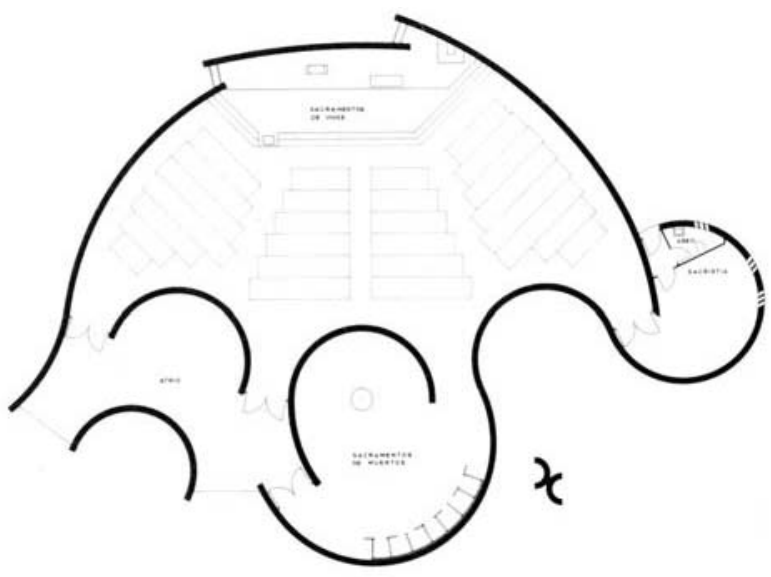

Iglesia para la misión dominicana de Formosa, Taiwan (1966). Proyecto.

En este sentido habría que entender el camino seguido por Miguel Fisac como un verdadero ejercicio ascético: el camino desde una relación de la criatura con su Creador basada en el temor y la distancia, hasta el entendimiento de su verdadera filiación divina, de su familiaridad y por tanto su proximidad con aquel mismo Dios. No obstante, ésta es una dimensión que, aunque conviene señalar en este punto, plantea cuestiones de índole espiritual que superan con mucho las ambiciones de este texto.

Sobre los tableros del estudio profesional de Miguel Fisac debieron coincidir los planos de Santa Ana con los de otros proyectos del mismo tipo: las parroquias de Santa María Magdalena en el madrileño polígono de Santamarca, la de Santa Cruz de Oleiros en A Coruña o el proyecto de iglesia para la misión dominicana en Formosa, todos ellos informados con criterios espaciales análogos aunque tocados, cada uno de ellos, por alguna especificidad.

En un momento especialmente prolífico en la carrera del arquitecto manchego, Fisac recibió un encargo análogo - un conjunto parroquial urbano - esta vez en A Coruña, donde propuso una variante de la solución de Santa Ana. Se trataba del proyecto de la iglesia y centro parroquial de Santa Cruz de Oleiros, conjunto que se asoma bellamente sobre la bahía coruñesa. Constituido por la iglesia como pieza protagonista, con su campanario vertical — contraste del conjunto- y la guardería-dispensario médico en un edificio independiente, forma un solo conjunto arquitectónico concebido como sucesión de recintos engendrados por muros de traza curva. Como queda dicho, conceptualmente se trata de una variante donde Fisac afina la gramática de sus hormigones y explora variaciones propias de un virtuoso. Se trata de un tema que domina, pero en el que siempre encuentra nuevos retos. Espacialmente Fisac avanza poco en esta bellísima obra gallega, dejando, no obstante y una vez más, un testimonio construido de su madurez arquitectónica. 


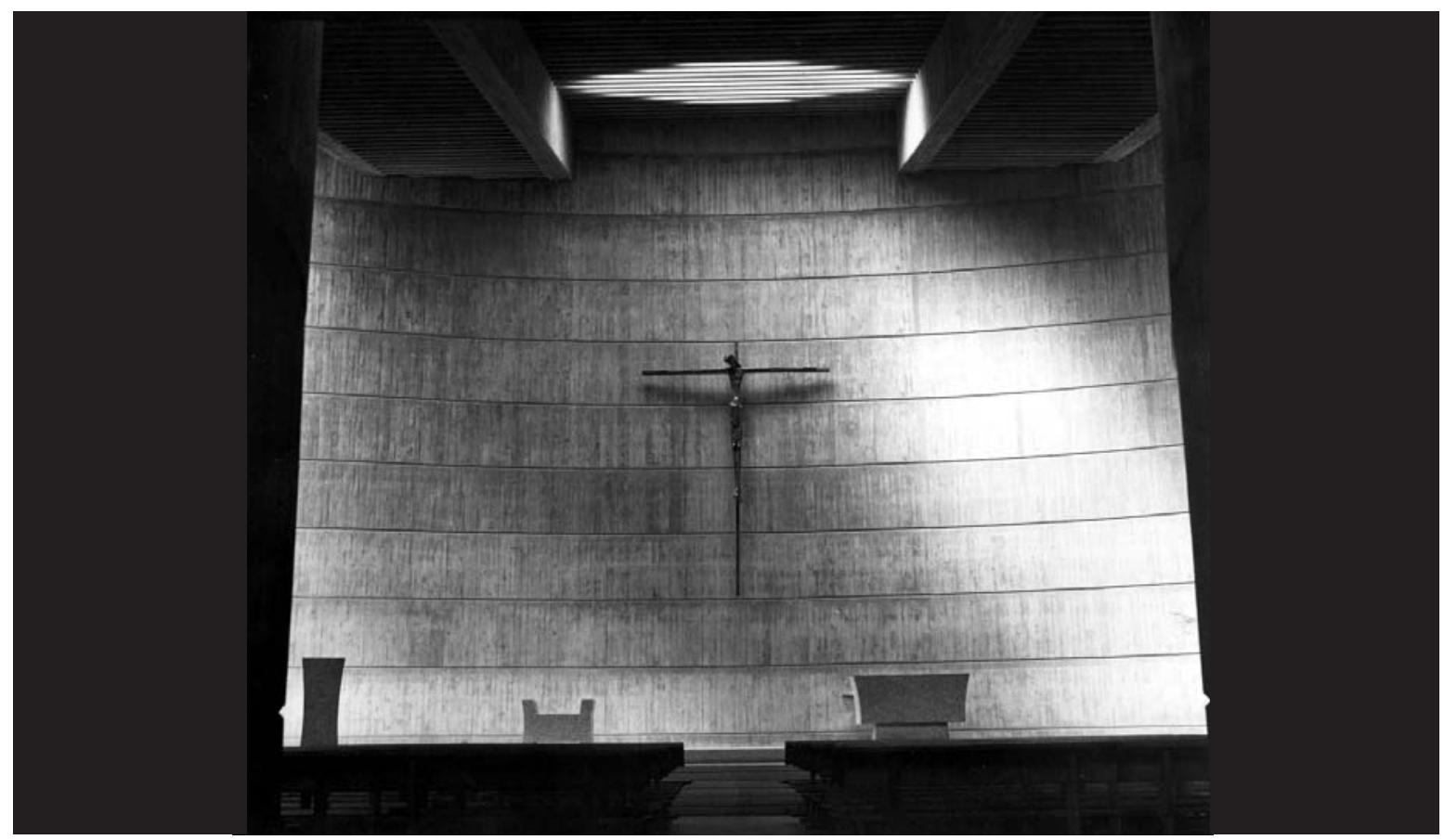

Complejo parroquial de Santa Cruz de Oleiros, A Coruña (1966/71).

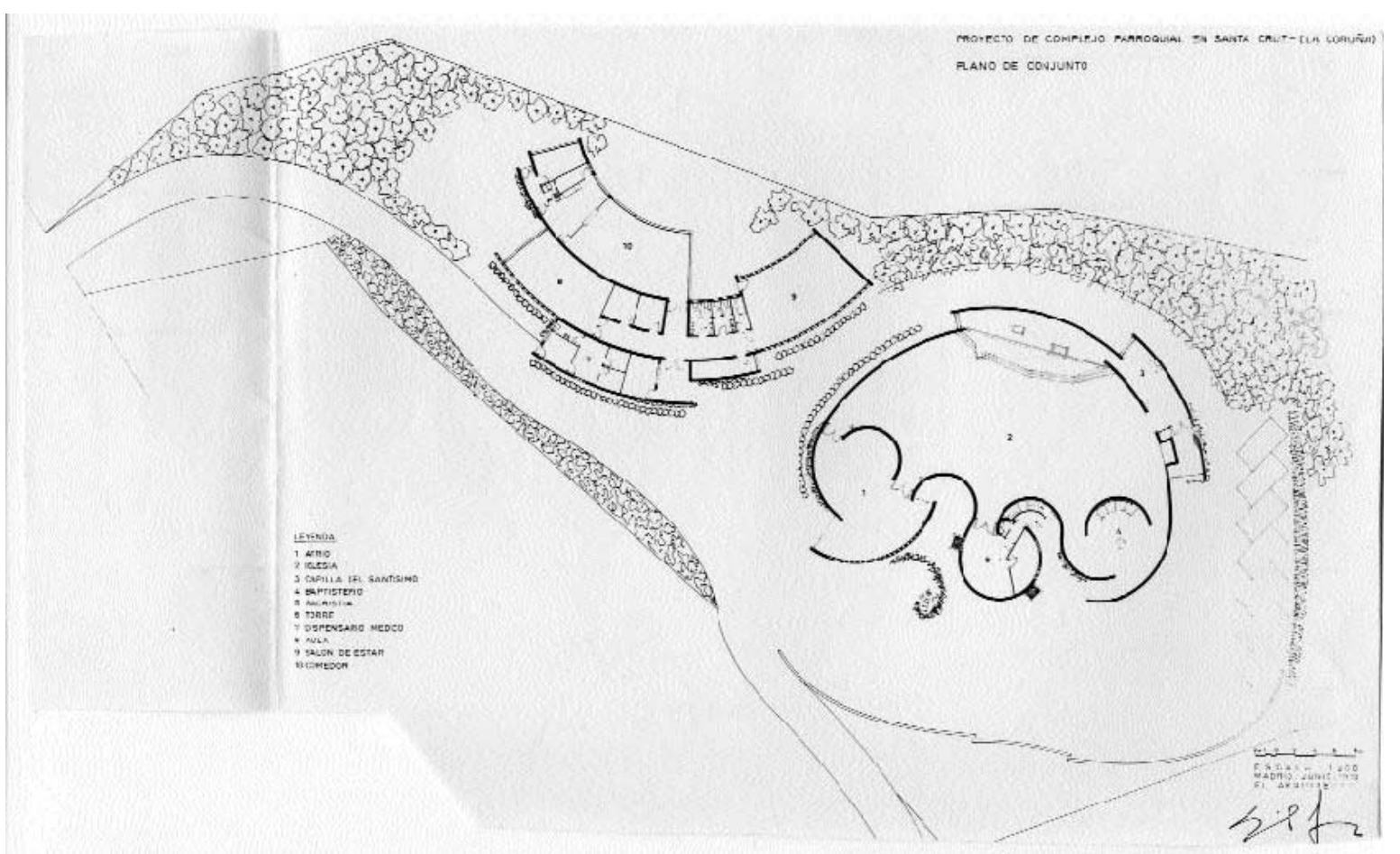


a similar assignment: an urban parish complex in A Coruña, for which he proposed a variant of Saint Anne's. This was the church and parish centre project of Santa Cruz of Oleiros, a building beautifully leaning out of the A Coruña bay. The church is the protagonist piece with a vertical belfry for contrast and the crèche-medical ward in an independent building, it integrates a single architectural unit conceived as a succession of precincts created by curved walls. As it was said, conceptually it was a variant where Fisac polished his concrete grammar and explored variations like a virtuoso. He is a master of the subject who always finds new challenges in it. Fisac did not make many spatial innovations in this beautiful Galician work, however, it is once more a constructed testimony of his architectural ripeness.

\section{Requiem}

During the 70s, the same Fisac who had experienced an extraordinary popularity for a Spanish architect in the 50s and 60s had to face several years of few projects and a certain social exclusion. The architect resorted to his religious avatars in order to explain that circumstance. Perhaps he thought that his peculiar wandering through the world of construction-associated techniques and structures was less important than it really was, because he was detached from the Spanish industry of the time. The truth is that those approaches, together with his particular idiosyncrasy, led him to a progressive isolation from which he would only recover in his final years, though not as much as he would have desired, thanks to new projects and works.

Thus, during the 70s, there is only news of some intervention on some of his previous works, such as the Dominican cemetery of Teologado in Alcobendas, as well as a series of refurbishments in La Mancha ${ }^{45}$, which certainly shows the precarious standing of his studio. You have to wait until the 80s in order to continue with the history of Miguel Fisac's churches, though not with the same scope of the 50 s or 60 s.

Certainly, at the threshold of the new decade, Fisac was assigned the project for a religious facility, this time for a Carmelite community in northern Madrid. It is unavoidable to compare it to the planning of the main facilities planned for the Dominicans in the 50s. Nevertheless, time had elapsed transforming many of the conditions which were then valid but, 30 years later, appeared obsolete and not feasible. Neither the Church, nor society, nor the architect was the same. In fact, the Church had experienced a certain "aggiornamento», following the expression and will of the so-called Good Pope John XXIII. The

\section{RÉQUIEM}

Durante la década de los setenta, el mismo Fisac que había vivido una popularidad extraordinaria para un arquitecto en la España de los años cincuenta y sesenta, debió enfrentarse a años de falta de encargos y de un cierto ostracismo social. El arquitecto acudía a sus avatares religiosos para explicar esta circunstancia, tal vez concediendo menos importancia de la debida a su peculiar deambular por el mundo de las técnicas asociadas a la construcción y a las estructuras, despegándose de la realidad de la industria española de la época. Lo cierto es que estos planteamientos, junto a su particular idiosincrasia, le condujeron a un progresivo aislamiento del que sólo fue recuperado en los últimos años de su vida, y ya nunca de la manera que él hubiera deseado, a través de encargos y de obras.

Así, durante la década de los setenta sólo tenemos noticias de alguna intervención en obras suyas anteriores, como el cementerio dominico del Teologado de Alcobendas, y una serie de restauraciones en el entorno geográfico manchego ${ }^{45}$, lo que en efecto revela la precariedad laboral de su oficina. Habría que esperar a la década de los ochenta para retomar la historia de las iglesias de Miguel Fisac, y ello con un alcance que ya nunca sería el de los años cincuenta o sesenta.

En efecto, al filo de la nueva década, Fisac fue requerido para proyectar un conjunto religioso, esta vez para una comunidad carmelita en el norte de Madrid. La comparación con el planteamiento de los grandes conjuntos proyectados en la década de los cincuenta para los dominicos resulta inevitable. No obstante, el inexorable paso del tiempo había transformado muchas de las condiciones que entonces eran válidas, y que treinta años después resultaban obsoletas e inviables. Ni la Iglesia, ni la sociedad, ni siquiera el arquitecto, eran los mismos. En efecto, la Iglesia había experimentado un cierto «aggiornamento», siguiendo la expresión y la voluntad del «Papa bueno» Juan XXIII. Los principios del Concilio Vaticano II se encontraban en proceso de traducción a la práctica común. La sociedad española se encontraba en plena transición democrática, con todo lo que ello llevó consigo de cambio de mentalidad y costumbres. Finalmente, Fisac — como se ha señalado más arriba - venía de sufrir su particular travesía por el desierto, después de años de precariedad laboral y olvido.

El encargo de Nuestra Señora de Altamira responde a un complejo parroquial en un barrio-dormitorio de la periferia de la ciudad. El hecho de que la parroquia estuviera encomendada a una orden religiosa y no a la Iglesia secular se traduciría únicamente en la necesidad de incorporar una pequeña residencia para los religiosos. Por lo demás, el arquitecto propuso un ejercicio de gran sencillez, alejado de la tensión plástica y de los vehementes planteamientos de otras épocas. Así, el proyecto carece del vigor de otros ejercicios y parece concentrarse en el juego geométrico sobre el presbiterio para responder a las solicitudes espaciales hechas por los carmelitas.

En palabras del mismo arquitecto, «los PP. Carmelitas tenían una idea muy clara del programa que querían desarrollar y que difería de otros más 

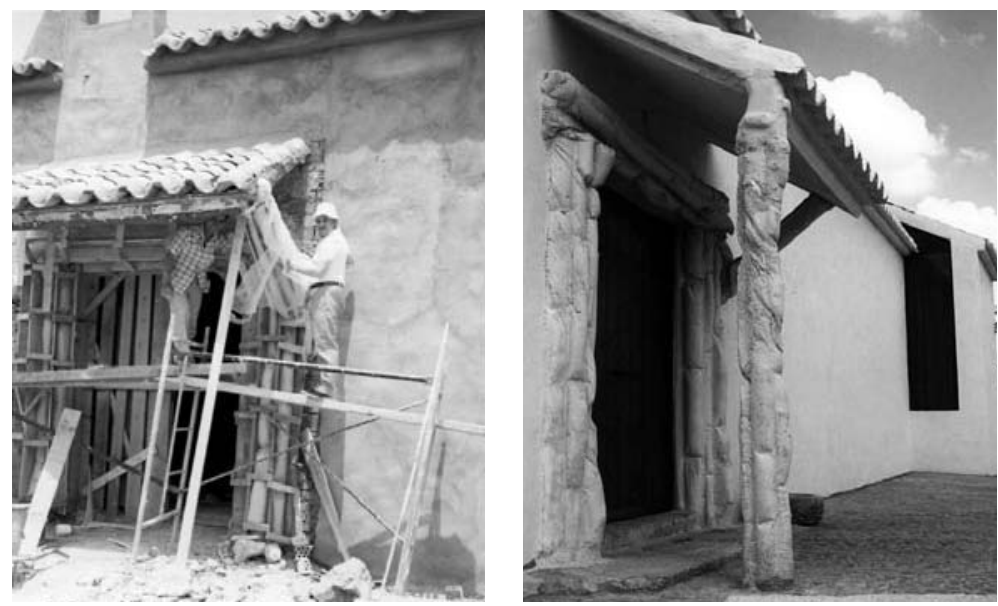

Reforma de la ermita del Santísimo Cristo Salvador del Mundo, Calzada de Calatrava (Ciudad Real, 1976). A la izquierda, el arquitecto en un andamio confeccionando un encofrado flexible. A la derecha, el pórtico terminado.

convencionales (...): por un lado querían que, si asistían pocos fieles a los actos litúrgicos, no diera la desagradable impresión de estar vacía y si asistían muchos cupieran (...) Diseñé un espacio geométrico, cúbico — de caja de zapatos que llamo yo- para conseguir tres espacios prismáticos triangulares neutros que se pueden o no utilizar» ${ }^{46}$. En efecto, esta expresa voluntad explica con precisión el despliegue espacial del templo, muy alejado de las estrategias polarizadas que caracterizaron las arquitecturas anteriores de este autor en este género.

Por otra parte, cabe abrir aquí un paréntesis de reflexión en torno al planteamiento figurativo requerido al arquitecto. En efecto, los religiosos «querían que el ambiente fuera el de una reunión festiva y comunitaria de fieles, huyendo de penumbras, recibimiento e imaginería penitencial. El recinto debía estar presidido por la figura de Cristo Resucitado» ${ }^{47}$. Esta opción figurativa admite una lectura teológica más profunda. Se trataría de acentuar el atractivo de la gloria inherente a la Resurrección frente al temor inspirado por el dolor de la Pasión. Más recientemente - y frente a la serie de Crucificados de Pablo Serrano que, de alguna manera, podrían identificar la imaginería moderna española de los años cincuenta y sesenta-, el joven escultor Javier Martínez Pérez - becario en la Academia Española de Bellas Artes de Roma en 1997 - ha producido ya una pequeña serie de Cristos resucitados, entre otros, para el complejo parroquial de Collado-Villalba (Madrid), de Ignacio Vicens y José Antonio Ramos, y para el centro parroquial de San Simón de Rojas en Móstoles, también en Madrid, de Miguel Ángel Santibañez Llinás.

Finalmente $-\mathrm{y}$ volviendo al conjunto carmelitano de Fisac-, este proyecto decanta otra de las obsesiones presentes en su última obra. Se trata de la prefabricación como paradigma constructivo. En este caso sería llevada al cerramiento de fachada mediante una pieza de hormigón donde principles of the II Vatican Council were being translated to the common practice. The Spanish society was going through its transition to democracy, with everything it entailed as regard a change of minds and habits. Finally, Fisac - as it was already mentioned - had suffered his own journey through the desert after years of labour instability and oblivion.

The assignment for Our Lady of Altamira responds to a parish complex in a working-class district in the outskirts of the town. The fact that the parish was commended to a religious order instead of the secular Church would only mean that it was necessary to build a small residential hall for the monks. Otherwise, the architect put forward a very simple exercise, one that was detached from the plastic tension and from the vehement approaches of past epochs. Thus, the project lacks the strength of other exercises and seems to concentrate in the geometrical game with the presbytery in order to respond to the Carmelites' spatial requirements.

In his own words: "The Carmelites had a very clear idea of the programme they wanted to develop and that differed from other more conventional ones (...): on the one hand, if few believers attended the liturgical celebrations, they did not want the church to look empty, and if a lot of them came, there should be enough room for them (...) I designed a geometrical, a cubic space, like a shoe-box, in order to achieve three neutral triangle prismatic spaces which can be used or not» ${ }^{46}$. Certainly, this explicit will accurately explains the spatial arrangement of the temple, which is very far away from the polarised strategies that characterised the author's previous architectures in this genre.

On the other hand, a reflection could be made on the figurative approach requested of the architect. In fact, the religious men wanted «the atmosphere to be that of a festive community gathering of the faithful, escaping from half-lights and penitential imagery. The precinct should be presided by a sculpture of the resurrected Christ ${ }^{47}$. This figurative option allows a deeper theological reading. It would have the purpose of highlighting the glory appertaining to the resurrection as opposed to the fear inspired by the Passion. More recently, and in contrast to the crucified Christs by Pablo Serrano which, somehow, could identify modern Spanish religious sculpture from the 50s and 60s, the young sculptor Javier Martinez Pérez - grantee at the Spanish Academy of Fine Arts of Rome in 1997-had already created a small series of resurrected Christs, some of them for the Collado-Villalba parish complex (Madrid), others by Ignacio Vicens and José Antonio Ramos, 
and others for Saint Simon de Rojas parish centre in Móstoles, also in Madrid, by Miguel Ángel Santibañez Llinás.

Finally, and going back to the Carmelites' building by Fisac -, this project portrays another obsession present in his last works: pre-fabrication as a constructive paradigm. This would be applied to the façade closing by means of a concrete piece where the author would sign by means of a soft shuttering treatment. This formula provides the building with a particular vibration, although it would be just anecdotic if it wasn't for all the personal research it entailed.

Time has gone by, and Fisac's Altamira complex shows more serene, less belligerent than in the immediate post-council years. This work has hardly a dramatic load, is clearer though less intense than most of the previous ones. At this small Madrid parish, Fisac appears to be tired of fighting; he does not give up but does not fight the way he used to in past times. Just like many other architects who have reached an undoubted but heterodox maturity, it could be said that Fisac is detached from the beauty of his last works. He does not need to prove his worth to anybody, he has almost said it all and this work only shows some personal traits which are almost anecdotic. The former discussion about the believers' arrangement around the altar is overcome by the lack of them. The mystical genre described by Moya according to the space lighting is obsolete in favour of an indiscriminate entry of light in the precinct, as a result of the proprietors' wish to manifest the glory of resurrection. The concrete bones are replaced with «vierendeel» ones which make the structure cheaper. The formal organics of the past is substituted by a much more restrained option. The former monumental scale is replaced with an almost domestic one, in a process that started many years ago.

Finally, the story of the small church of Pumarejo de Tera (Zamora) is a memorable one. Fisac was almost acclaimed to rebuild his former parish. The architect would always keep a warm memory of this occasion, since it meant for him an example of humanity which was a concept treasured by him throughout his whole life: "The execution of this church is the most beautiful sociological phenomenon I have experienced in my long career. The church in the Zamora small-town had collapsed and the major had told a dear friend of mine, Doctor Ramos de Castro, that the parishioners would be thrilled if I could build the new church.

"After many anecdotes and with my own reconsideration and some explanations on how to put up walls, every inhabitant, the men setting el arquitecto estamparía su firma mediante un tratamiento con un encofrado blando. Esta fórmula confiere una vibración particular al conjunto, si bien podría no pasar de la categoría de anécdota si no fuera por lo que significa de investigación personal de su autor.

Ha pasado el tiempo, y en el complejo de Altamira Fisac se nos muestra más sereno, menos beligerante que en los inmediatos años del postconcilio. Se trata de una obra sin apenas carga dramática, mucho más luminosa aunque también menos intensa que la mayoría de las obras anteriores. En esta pequeña parroquia madrileña, Fisac se nos antoja cansado de la pelea; no se rinde, pero tampoco planta la batalla de otros tiempos. A imagen de otros arquitectos que han alcanzado una madurez incuestionable aunque heterodoxa, podría decirse que Fisac se desentiende de la belleza de sus últimas obras. A estas alturas no necesita demostrar nada a nadie, ya lo ha dicho casi todo y en esta obra sólo apunta aspectos que, por personales, resultan casi anecdóticos. La antigua discusión de la mejor ordenación de los fieles alrededor del altar queda superada ante la carencia de fieles. El género místico - descrito por Moya en función de la iluminación del espacio - queda obsoleto ante la entrada indiscriminada de luz en el recinto, consecuencia del deseo de la propiedad de manifestar la gloria asociada a la Resurrección. Los huesos de hormigón son sustituidos por vigas «vierendeel» que abaratan la estructura. El organicismo formal de otra época es sustituido por una opción mucho más contenida. La antigua escala monumental es sustituida — en un proceso iniciado muchos años antes- por una escala casi doméstica.

Finalmente, resulta absolutamente memorable la historia de la pequeña iglesita de Pumarejo de Tera, en la provincia de Zamora, donde Fisac fue requerido casi por aclamación para reconstruir la que fuera su parroquia. El arquitecto guardó siempre una cariñosa memoria de esta ocasión por lo que tuvo de muestra de humanidad, un concepto especialmente valorado por Fisac a lo largo de toda su vida: «La ejecución de esta iglesia es el fenómeno sociológico más bonito que he vivido en mi dilatada vida profesional. La iglesia del pequeño pueblo zamorano se había hundido y su alcalde había comentado a mi querido amigo el doctor Ramos de Castro la ilusión que le haría a los vecinos que yo les hiciera la nueva iglesia.

"Después de diversas anécdotas y con mi personal replanteo y explicaciones sobre la manera de hacer muros, todos sus habitantes, hombres para asentar las piedras de pedernal y mujeres y niños para hacer el mortero, ejecutaron los muros y se remató la totalidad de la obra.

»Mi nombramiento como hijo adoptivo del lugar fue, sin duda, uno de los más entrañables honorarios que he recibido» ${ }^{48}$.

Esta experiencia participativa y de contacto directísimo con los futuros usuarios, la construcción y los materiales, cierra de alguna manera un ciclo. Siempre que se trataba de la construcción de su primera obra - la capilla del CSIC - Fisac evocaba sus explicaciones a los albañiles, subido en lo alto de los andamios, recurriendo a una naranja 


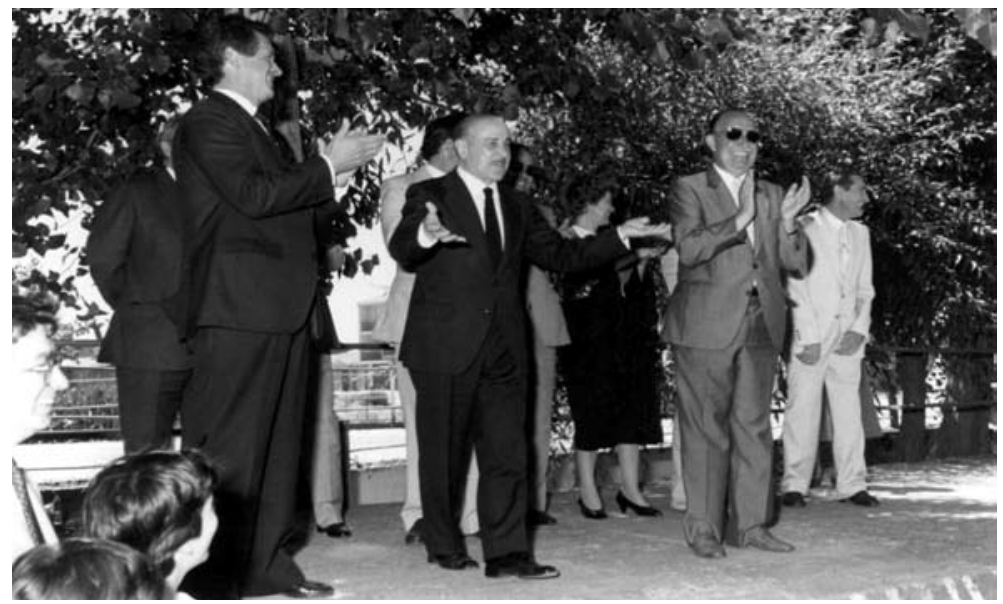

Iglesia parroquial, Pumarejo de Tera (Zamora, 1984).

para explicar la geometría y la construcción de las bóvedas vaídas. Con orgullo refería como, en última instancia y ante la falta de pericia de los obreros, él mismo las había trazado y construido. En Pumarejo de Tera el arquitecto volvió a los andamios — cerrando, en efecto, aquel ciclo-para formar a sus obreros-constructores, aunque en esta ocasión no fueran profesionales.

Es posible que en aquellos días felices de Zamora, el arquitecto reflexionase que si lo que las reformas conciliares pretendían era la participación de los fieles, ninguna de sus obras lo había conseguido tanto como aquella en la que la obligada autoconstrucción ante la falta de recursos consiguió la identificación de los fieles con su templo.

Por otra parte, también en esta pequeña obra rural Fisac alcanzó - puede que como en ninguna otra - otro de los anhelos constantes de su carrera: lo que él mismo denominaba la humanización de la arquitectura. Cuando después de sus viajes para conocer de primera mano las arquitecturas de los maestros del Movimiento Moderno, Fisac explicaba su personal insatisfacción con aquellos modelos, hablaba precisamente de la ausencia de aquel valor.

Después de estas últimas experiencias — plenas de satisfacciones personales, casi íntimas, pero también de renuncias y puede que de amargura profesional-, Miguel Fisac aún tuvo tiempo de entonar un postrero canto del cisne en el terreno que nos ocupa. Tuvo lugar en la iglesia de la urbanización Torre Güil en Murcia, proyectada y construida en fecha tan tardía como 1991. Cerrada su oficina del Cerro del Aire y casi abandonada la práctica profesional, Fisac fue requerido para un último ejercicio en un contexto de casi nulo carácter y con unas condiciones de gran libertad creativa, aunque relativamente escasos recursos materiales. Para su ejecución Miguel Fisac contó con el arquitecto Emilio Vicedo, quien recogía

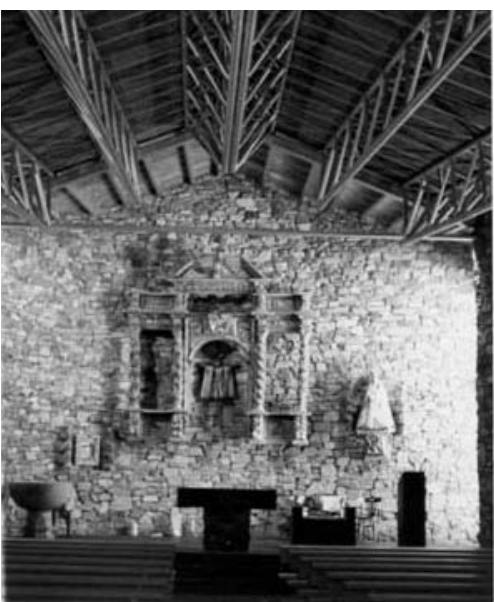

down the flint stones and the women and children making the mortar, helped in executing the walls and the whole work was accomplished. »My being appointed as adopted son of the place was certainly one of the warmest awards I ever got ${ }^{48}$.

This experience of participation and very direct contact with the future users, building and materials somehow completed a cycle. Whenever he referred to the construction of his first work, the CSIC chapel-, Fisac would recall his explanations to the masons, perched on the scaffolding, he used an orange in order to explain the geometry and construction of domes with four vertical plans. vaidas. He was proud to explain how, as a last resort and given the masons' lack of skills; he had drawn and made them himself. In Pumarejo de Tera the architect returned to the scaffolding, thus closing that cycle, in order to train his workersbuilders, though they were not professionals then. Possibly during those happy days in Zamora, the architect could reflect upon the fact that if the council's reforms aimed at the participation of the faithful, none of his works had achieved it as well as that one, in which the compulsory selfconstruction caused by a lack of resources got the faithful to identify themselves with their temple. On the other hand, it is true that Fisac achieved with this small rural work - maybe better than with any other- another constant craving in his career: what he called the humanisation of architecture. When Fisac explained his discontent with the architecture of the Modern Movement masters after his trips where he got acquainted 
with them, he was precisely referring to the lack of that value.

After these last experiences - crowded with personal, almost intimate satisfaction, but also with renunciation and maybe professional bitterness-Miguel Fisac still had time for a last swan's chant in his field. That happened at the church of Torre Güil condo in Murcia, projected and built as late as 1991. His Cerro del Aire studio had been closed down and his professional practice almost abandoned when Fisac was requested to make one last exercise in a context of practically zero personality but with a huge creative freedom, though with relatively scarce material resources. Miguel Fisac had the support of architect Emilio Vicedo, who would compile the master's ideas and drafts and turn them into the execution project, thus testing the type of collaboration to be used by the architect from La Mancha since the final closure of his professional studio during the 80 s.

This was a basic parish complex measuring hardly 400 square meters and located at a condo in the outskirts of Murcia. With an elementary asymmetric nave, a sacristy and a conference hall, all of this was articulated through a small triangle court, however, its interest lies in the constructive system: "The whole of the walls and cover have been made with a concrete slab of uniform thickness, shuttered with prefabricated with wooden panels wrapped in a plastic layer providing a bright and polished texture of top quality ${ }^{49}$.

Nevertheless, compared to the Pumarejo case, Fisac kept a relative distance from the project execution. He paid few visits to the work; he was physically impaired and aware of the fact that his time was almost done. In his last few years, being aware of this fact, he relativised his interest in architecture and was intent -together with her life-companion, Ana María- on a spiritual quest in preparation of his own death, seen as a meeting with the one for who he had projected the most important collection of sacred spaces of the Spanish 20th century:

"I feel impatient, as if I was about to set off in a desired trip.

"And that is not because I intend to go anywhere, but death will come looking for me, with no dark reference to the Parches, without the evil Athropos cutting off my life rope and thus ending it all. It is me who will be waiting for the good death which comes to help me move on from this life to the next one. "Full of hope that I will see the Lord, that he loves me and waits for me» ${ }^{50}$.

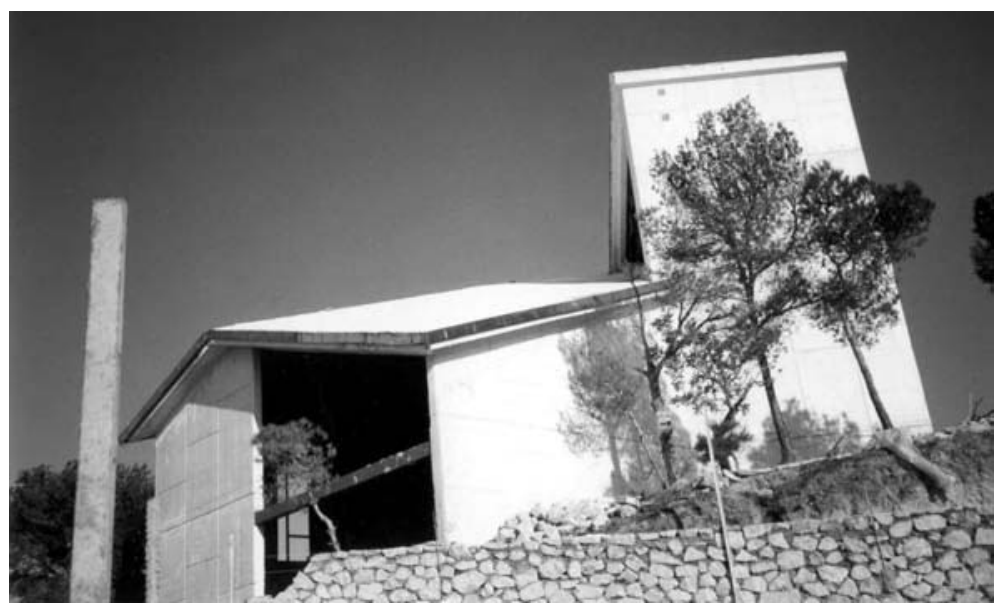

Iglesia parroquial de la urbanización Torre Güil, Murcia (19991).

las ideas y los croquis del maestro trasformándolos en el proyecto de ejecución, ensayando así el tipo de colaboración que el arquitecto manchego utilizaría desde el cierre definitivo de su oficina profesional durante la década de los ochenta.

Se trata de un elemental complejo parroquial de apenas cuatrocientos metros cuadrados situado en una urbanización de las afueras de Murcia. Dotado de una elemental nave asimétrica, sacristía y salón de actos, todo ello articulado a través de un mínimo patio triangular, su interés reside en su sistema constructivo: «Se ha ejecutado la totalidad de muros y cubierta con una losa de hormigón armado de espesor uniforme, encofrada con paneles prefabricados de madera revestidos con una membrana de plástico que proporciona una textura brillante y pulida de gran calidad» ${ }^{49}$.

No obstante, frente al caso de Pumarejo, Fisac se mantuvo relativamente distante de la ejecución de este proyecto, acudiendo en contadas ocasiones a la obra, físicamente limitado y consciente de que su tiempo estaba casi cumplido. Consecuencia de esta conciencia fueron sus últimos años en los que, relativizando su interés por la arquitectura, acentuó su empeño — compartido con su compañera de toda la vida, Ana María - en una búsqueda espiritual, preparación de su propia muerte, entendida como encuentro con Aquél para quien había proyectado la más importante colección de espacios sacros del siglo XX en el ámbito español:

«Me siento impaciente, como si de un deseado viaje se tratara.

"Y no porque piense marcharme yo a ninguna parte, sino que será la muerte la que a buscarme venga, sin lóbregas referencias a las Parcas, sin la malvada Átropos cortando el hilo de mi vida con lo que todo acaba. Sino esperando yo a la buena muerte, que a ayudarme viene a pasar de esta vida a la otra.

»Lleno de esperanza de que veré al Señor, que me espera y me ama» ${ }^{50}$. 
EDUARDO DELGADO ORUSCO

4

Almager 18 de Junis de 2006

Querider Eduarder:

He renidr a Ciuded Roel dnade le har dadr un homenaje pecirs a hipul.

$y$ dasde aqué piers contestante:

La verdad es que knigual paso' al otho lado dulcemente. E'l estaba muy preparado y muy dispuesto.

Habianos hablado durante muchas horas $\gamma$ muchss dias de lo que era la muerte. gniguel me explicaba que sto se trataba de salir del cuerpo, y por tanto pro tenee, ya, ni espacio ni tiempo.

gnigual estata segure que después estaria más vivo que nunca.

"Espers no dudar y dar este paso bien", me decia. If er higo francamente bien.

gracias pretus lineas tan sentides o un ahazs de

Qua hané

Carta autógrafa de Ana María Badell al autor.

158 I Congreso Internacional de Arquitectura Religiosa Contemporánea 
In order to finish my presentation, I would like to share with you the letter sent to me by Ana Maria as response to my condolences.

Almagro, 18 June 2006

Dear Eduardo:

I have come to Ciudad Real where they have paid a beautiful tribute to Miguel.

And I would like to answer you from here:

The truth is that Miguel moved on to the other side sweetly. He was quite ready and well-disposed. We had spoken for many hours and days about what death is. Miguel explained to me that it was just leaving your body behind, and, as result, having no more space or time.

Miguel was sure that later he would be more alive than ever:

"I hope that I will not hesitate and will take this step fine», he told me. And he did really well.

Thanks for your deeply felt lines, and hugs from

Ana María
Para terminar mi intervención, quiero finalmente compartir con vosotros la carta que en contestación a mi pésame me escribió Ana María:

Almagro, 18 de junio de 2006

Querido Eduardo:

He venido a Ciudad Real donde le han dado un homenaje precioso a Miguel.

Y desde aquí quiero contestarte:

La verdad es que Miguel pasó al otro lado dulcemente. Él estaba muy preparado y muy dispuesto. Habíamos hablado durante muchas horas y durante muchos días de lo que era la muerte. Miguel me explicaba que sólo se trataba de salir del cuerpo, y por tanto no tener, ya, ni espacio ni tiempo.

Miguel estaba seguro que después estaría más vivo que nunca.

«Espero no dudar y dar este paso bien», me decía. Y lo hizo francamente bien. Gracias por tus líneas tan sentidas, y un abrazo de

Ana María
Certainly, the jury was integrated by José Ignacio Linazasoro Rodríguez, Víctor López Cotelo, Rafael Manzano Martos and Salvado Perez Arroyo, and they considered that the architect from Daimie merecedeserved the award thanks to the top quality of his work and,
in particular, due to his extremely important contribution to Spain's in particular, due to
religious architecture.

religious architecture. 2 (1997), pag. 12.

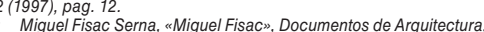
10 (1989), Monographic issue, pag. 9.

"Thus, in that genre, we may recall plenty of Castillian churches with very dark naves and low ceilings, with presbyteries with high domes and huge windows, generally Gothic ones. They usually say that this presbytery was the start of a total reconstruction of the church which was never made. Whether these stories are true or not, the reality is that this type of temple was deliberately made in the 16th century in the Saviour, in Úbeda, with the plan conceived as a unit, and in Renaissance forms, by Vandelvira. This was not a single case. Fisac's Holy Ghost church is a recent evidence of thats. (Luis Moya Blanco, in Several authors, "Concurso de anteproyectos de la Iglesia Parroquial de San Esteban The

"The idea of placing the dome above the altar is followed in many Romanesque temples. This is the configuration of the Confession altar in Rome's Saint Peter and, in Spain, among many examples; we could quote the Granada cathedral and the primitive project for en Madrid", Revista Nacional de Arquitectura, 78 (1948), pag. 199). 6 Ibidem, pag. 205-206.

It is scarcely known that architect Ricardo Fernández Vallespin, Fisac's mentor in his frist professional steps, had made a similar trip which undoubtedly inspired that of the architect from La Mancha: "In the months of March and April 1947, he travelled to Switzerland, Holland, the Scandinavian countries and England. He visited the cities of Basil, Bern, Geneva, Zurich, Amsterdam, Rotterdam, Haarlem, Copenhagen, Gothenburg, Stockholm and London. This European tour is very important for the historiography of Spanish architecture, given that, except for Pedro Muguruza who went to Sweden on an official visit as General Manager of Architecture at the Latin-American Architecture Exhibition, it was the first trip by a Spanish architect registered after the civil war through those countries". Eduardo Delgado Orusco and Carlos San Antonio Gomez, "La arquitectura de Ricardo Fernández Vallespin para el CSIC o la imposible modernidad de los cuarenta" en:
Varios autores, "Los brillantes 50.38 proyectos", Eunsa, Pamplona, 2004; pag. 132-143.

2004; pag. 132-143.
8 Cf. "Lo clásico y lo español», Revista Nacional de Arquitectura, 78 (1948), pág. 197-198; "Las tendencias estéticas actuales", Boletín de la Dirección General de Arquitectura, 9 (1948), pág. 21-25; «Estética de Arquitectura", Boletín de la Dirección General de Arquitectura, 11 (1949), pág. 13-14; «Orientaciones y desorientaciones de la Arquitectur religiosa actual», Árbor, 39 (1949), pág. 379-390 y "Orientaciones desorientaciones de la arquitectura religiosa actuals, Boletín de la Dirección General de Arquitectura, 13 (1950), pág. 9-11. In this regard, please note that the Bulletin of the General Directorate of Architecture became, at least since 1947, a meeting point for those unhappy with the stagnation of Spanish architecture. Gabriel Alomar, Francisco Cabrero, José María Sostres or Francisco Mitjans, together with Miguel Fisac, among others, were the ones who expressed their discontent.

These were the manifesto signatories: Rafael Aburto, Pedro Bidagor, Francisco Cabrero, Eusebio Calonge, Fernando Chueca, José Antonio Dominguez Salazar, Rafael Fernández Huidobro, Miguel Fisac, Damián Malmues, Luis Garcia Palencia, Fernando Lacasa, Emilio Larrodera, Miguel, Francisco Moreno López, Juana Ontañón, José Luis Picardo, Francisco Prieto Moreno, Mariano Rodríguez Avial, Manuel Romero and Secundino Zuazo.
En efecto, el jurado integrado para la ocasión por José Ignacio Linazasoro Rodríguez, Víctor López Cotelo, Rafael Manzano Martos y Salvador Pérez Arroyo consideró al arquitecto de Daimiel merecedor del galardón por la alta calidad de su obra y, muy especialmente, por su importantísima aportación a la arquitectura religiosa de nuestro país.

2 Juan Plazaola Artola, "Miguel Fisac. El afán de crear», Ars Sacra, 2 (1997), pág. 12.

3 Miguel Fisac Serna, "Miguel Fisac», Documentos de Arquitectura, 10 (1989), Número monográfico, pág. 9.

4 "Así, de ese género pueden recordarse muchas iglesias castellanas de nave muy oscura y techumbre baja, con presbiterio de bóvedas altas y grandes ventanales, generalmente gótico, de las que suele decirse que este presbiterio fue el principio de una reconstrucción total de la iglesia que no llegó a realizarse. Sean o no ciertas tales historias, la realidad es que en el siglo XVI se hizo deliberadamente esta forma de Templo en el Salvador, de Úbeda, con plano concebido como una unidad, y en formas del Renacimiento, por Vandelvira. Y no quedó como caso único. La iglesia del Espíritu Santo, de Fisac, es prueba reciente de ello" (Luis Moya Blanco, en Varios autores, "Concurso de anteproyectos de la Iglesia Parroquial de San Esteban Protomártir. Cuenca”, Arquitectura, 25 (1961), pág. 13-51.

5 «Esta idea de colocar la cúpula sobre el altar es el seguido en muchos templos románicos. Es la disposición que tiene el altar de la Confesión de San Pedro de Roma, y, en España, entre otros ejemplos, se pueden citar el de la Catedral de Granada y el proyecto primitivo de la Catedral de Valladolid» (Miguel Fisac Serna, "Iglesia del Espíritu Santo, en Madrid», Revista Nacional de Arquitectura, 78 (1948), pág. 199).

6 Ibidem, pág. 205-206

7 Resulta poco conocido que el arquitecto Ricardo Fernández Vallespín, mentor de Fisac en sus primeros pasos profesionales, había realizado un viaje análogo, indudablemente inspirador del propio arquitecto manchego: "En los meses de marzo y abril de 1947, viajó a Suiza, Holanda, los países escandinavos e Inglaterra. Visitó las ciudades de Basilea, Berna, Ginebra, Zurich, Amsterdam, Rotterdam, Haarlem, Copenhague, Goteborg, Estocolmo y Londres. Este periplo europeo tiene una gran importancia para la historiografía de la arquitectura española ya que, con la excepción de Pedro Muguruza que fue a Suecia en visita oficial como Director General de Arquitectura a la Exposición Iberoamericana de Arquitectura, es el primer viaje, posterior a la Guerra Civil, del que se tenga constancia de un arquitecto español por esos países». Eduardo Delgado Orusco y Carlos San Antonio Gómez, "La arquitectura de Ricardo Fernández Vallespín para el CSIC o la imposible modernidad de los cuarenta» en: Varios autores, "Los brillantes 50. 38 proyectos", Eunsa, Pamplona, 2004; pág. 132-143.

8 Cf. "Lo clásico y lo español», Revista Nacional de Arquitectura 78 (1948), pág. 197-198; "Las tendencias estéticas actuales», Boletín de la Dirección General de Arquitectura, 9 (1948), pág. 21-25; "Estética de Arquitectura», Boletín de la Dirección General de Arquitectura, 11 (1949), pág. 13-14; "Orientaciones y desorientaciones de la Arquitectura religiosa actual», Árbor, 39 (1949), pág. 379-390 y "Orientaciones y desorientaciones de la arquitectura religiosa actual», Boletín de la Dirección General de Arquitectura, 13 (1950), pág. 9-11. En este sentido, cabría apuntar que el Boletín de la Dirección General de la Arquitectura se constituyó, desde al menos 1947, en punto de encuentro para los «descontentos» con la situación de estancamiento de la arquitectura española. Gabriel Alomar, Francisco Cabrero, José María Sostres o Francisco Mitjans, junto a Miguel Fisac, entre otros, fueron las firmas que manifestaron aquel desencanto.

9 Los firmantes del manifiesto fueron: Rafael Aburto, Pedro Bidagor, Francisco Cabrero, Eusebio Calonge, Fernando Chueca, José Antonio Domínguez Salazar, Rafael Fernández Huidobro, Miguel Fisac, Damián Galmés, Luis García Palencia, Fernando Lacasa, Emilio Larrodera, Manuel López Mateos, Ricardo Magdalena, Antonio Marsá, Carlos de Miguel, Francisco Moreno López, Juana Ontañón, José Luis Picardo, Francisco Prieto Moreno, Mariano Rodríguez Avial, Manuel Romero y Secundino Zuazo. 
Sobre la "relativa» trascendencia del "Manifiesto" en la cultura y subsecuentes realidades arquitectónicas españolas, no encuentro mejor explicación que la del ensayo "La visión arquitectónica de la Alhambra: el manifiesto de 1953", de Ángel Isac, publicado en la reedición del "Manifiesto de la Alhambra» a cargo de la Fundación Rodríguez-Acosta y la Delegación de Granada del Colegio Oficial de Arquitectos de Andalucía Oriental (Granada, 1993).

${ }^{10}$ "Orientaciones y desorientaciones de la arquitectura religiosa actual», cit., pág. 9-11.

11 En efecto, se trata de un modelo formal importado de los templos realizados por autores como Dominikus Böhm o Rudolf Schwarz. Precisamente para este último autor, aquella fórmula es una de las derivadas de sus investigaciones teóricas, realizadas varios años antes de la mano del filósofo y teólogo Romano Guardini. Esas investigaciones fueron recogidas en su libro "Vom Bau der Kirche» (Schneider, Heidelberg, 1947 (1932)).

12 De ser así, este conocimiento habría sido a través de alguna publicación, ya que su célebre viaje a los países nórdicos - Suecia y Dinamarca-, que además incluyó a Francia, Suiza y Holanda en su recorrido, no se produjo hasta noviembre-diciembre de ese mismo año.

${ }_{13}$ Entre los primeros arquitectos seguidores de este recurso - además de Asís Cabrero y Rafael Aburto con su proyecto de "Catedral para Madrid» - se encuentran José Luis Fernández del Amo, Alejandro de la Sota y Fernando Cavestany, sorprendentemente los tres ligados al Instituto Nacional de Colonización, donde por primera vez pusieron en práctica este recurso. Fernández del Amo en sendos proyectos rechazados para Torres de Salinas -mayo y diciembre de 1951-; Sota en la iglesia parroquial -esta vez síconstruida- del poblado de Esquivel -el proyecto del templo es de octubre de 1952-; y Cavestany en la iglesia parroquial de Estella del Marqués -diciembre de 1953-.

${ }^{14}$ En este punto, además del mencionado primer "gran viaje» por tierras europeas, Fisac ya había realizado el "segundo", en agosto de 1951, en el que, frente a la relativa dispersión del anterior, se había dirigido - significativamente para la historia que estamos contando- exclusivamente a Alemania.

15 Todos los proyectos de Miguel Fisac para la orden dominicana lo fueron para esta Provincia, encargada de las misiones en Extremo Oriente. Los encargos vinieron del Provincial padre Sancho, amigo personal de Josemaría Escrivá de Balaguer -fundador del Opus Dei- y formador de los primeros sacerdotes de esa institución, a la que Fisac pertenecía en aquel entonces.

Además del conjunto de Arcas Reales y el de Alcobendas, Fisac proyectó para la Provincia de Nuestra Señora del Rosario de Filipinas, la ampliación del convento de Santo Tomás en Ávila, en 1960, y el proyecto de misión dominicana en Formosa, en 1966, cuya iglesia participa de las mismas inquietudes formales que la iglesia de Santa Cruz de Oleiros, en A Coruña.

${ }^{16}$ Cf. "Colegio Apostólico de los PP. Dominicos en Valladolid", Revista Nacional de Arquitectura, 157 (1955), pág. 3-9 y Varios autores, "Sesión de Crítica de Arquitectura dedicada a la iglesia de los PP. Dominicos de Valladolid", Revista Nacional de Arquitectura, 157 (1955), pág. 10-19.

17 En el exterior del ábside, la imagen de Santo Domingo es una fundición en aluminio de Jorge Oteiza, autor también de las figuras junto a la cruz en la fachada posterior. En el interior, el grupo escultórico de la Virgen del Rosario con Santo Domingo es de José Capuz; los relieves del Vía Crucis son de Cristino Mallo y las vidrieras de la iglesia, sobre temas del rosario, de José María de Labra; Francisco Farreras y otros hicieron las imágenes sobre los altares de las capillas laterales; Susana Polac, las figuras de piedra en la entrada y el mosaico del refectorio; Antonio Rodríguez Valdivieso, los azulejos de los comedores de alumnos; y Álvaro Delgado, la pintura del retablo.

18 Intervención de Miguel Fisac en: Varios autores, "Sesión de Crítica de Arquitectura dedicada a la iglesia de los PP. Dominicos de Valladolid", Revista Nacional de Arquitectura, 157 (1955), pág. 18.

19 Cf. Salvador Mata Pérez, "Colegio Apostólico de los PP. Dominicos", en: Celestino García Braña y Fernando Agrasar Quiroga (eds.), "Arquitectura moderna en Asturias, Galicia, Castilla y León. Ortodoxia, márgenes y transgresiones», COAA/COAG/COACLE/COAL, 1998, pág. 230.

${ }^{20}$ En una entrevista con el padre José María Javierre S.J. publicada en la revista ARA, el arquitecto manifestaba sintéticamente su opinión al respecto: "La imagen de la Virgen, entre el ambón y la sede; así queda como mediadora, cercana al pueblo y saliendo del pueblo. En el altar la cruz, el crucifijo. No más imágenes. Los titulares del templo pueden tener su imagen, su símbolo o su inscripción en los atrios" (Cf. "Las imágenes en el templo. ¿Cuántas? ¿Cuáles? ¿En qué orden?», ARA, 10 (1966), pág. 37.

${ }_{21}$ Conversando personalmente con el arquitecto, éste me refería la historia de la vidriera. Al parecer a través de Susana Polac, le fue presentado el vitralista Adolfo Winternitz, cuñado de la escultora. Fisac le explicó lo que quería: una composición exclusivamente en tonos rojos, aludiendo al carácter martirial del titular del conjunto. Después de una serie de aproximaciones se llegó al acuerdo de lo ideado por Fisac, y Winternitz envío el diseño a los talleres de la ciudad de Lausana donde se ejecutaron los vidrios. Al llegar a Alcobendas - «una vez pagados y pasada la aduana»- Fisac descubrió que el diseño no era el aprobado, si no uno de los primeros propuestos por el vitralista. La devolución resultaba imposible, pues la vidriera se ajustaba al diseño enviado a Suiza por Winternitz.

${ }_{22}$ Cf. Ricardo de la Bastida Bilbao, "La construcción de templos parroquiales en la diócesis de Vitoria", Revista Nacional de Arquitectura, 72 (1947), pág. 346-351.

${ }^{23}$ Eduardo Delgado Orusco, "Porque vivir es difícil. Conversaciones con Javier Carvajal», Servicio de publicaciones de la Universidad Camilo José Cela, Ávila, 2002; pág. 44 y 53.

${ }^{24}$ Nacido en Hijar, provincia de Teruel en 1911 y fallecido en el verano de 2006 en Zaragoza, donde residía desde hace mucho tiempo, Francisco Peralta Ballabriga fue promovido obispo de la diócesis de Vitoria en 1955, cargo en el que permaneció hasta que Pablo VI aceptó su renuncia en 1978.

25 El prelado italiano Giacomo Lercaro (Quinto-al-mare/Génova, 1891-Roma, 1976), arzobispo de Bolonia desde 1952, fue creado Cardenal en 1953. Bien preparado intelectualmente y consciente de la necesidad de adaptación de la Iglesia a la cultura de su tiempo, fue el responsable del concurso de excelentes arquitectos en esta labor: Le Corbusier, Alvar Aalto, Glauco Gresleri, etcétera. Su obra escrita marcó también la pauta a seguir para el sector más culto de la Jerarquía. En 1964, después de haber sido nombrado moderador del Concilio Vaticano II -en el que representó la tendencia más favorable a una apertura-, el Cardenal Lercaro fue nombrado presidente del "Consilium ad exsequendam constitutionem liturgicam", órgano creado por la Santa Sede para la debida interpretación y aplicación de las reformas litúrgicas.
About the relative transcendence of the Manifiesto in culture and is fo subsequent Spanish architectural realities, the best explanation is found in the essay "La vision arquitectonica de la Alhambra: el the Manifiesto da and the Granada Delegation of the Colegio Oficial de Arquitectos de Andalucia Oriental (Granada, 1993).

An "Orientaciones y desorientaciones de la arquitectura religiosa

"Orientaciones y des
actual"s, quote, pag. 9-11.

Certainly, it is a formal model imported from the temples mad

by authors such as Dominikus Böhm or Rudolf Schwarz. With regard to the last author, that formula is derived form his theoretical research done Several years earlier together with the philosophe and theologian Romano Guardini. That research was compiled in his book «Vom Bau der Kirche» (Schneider, Heidelberg, 1947 (1932)). 2 If that was so, this knowledge would have been obtained from som publication, given that his famous trip to the Scandinavian countries (Sweden and Denmark) which also included France, Switzerland and Holland, took place in November-December of the same year.

13 Among the first architects following that resort - apart from Asis Cabrero and Rafael Aburto with his project Cathedral for Madrid - w may quote José Luis Fernández del Amo, Alejandro de la Sota and Fernando Cavestany, the three of them surprisingly linked to the resort. Fernández del Amo did so in two rejected projects for Torres de Salinas - May and December 1951-; Sota in the accomplished de Salinas -May and December 1951-; Sota in the accomplished parish church of Esquivel -the temple project dates from October - December 1953-.

${ }_{14}$ In this regard, apart from the already mentioned first big trip around Europe, Fisac had already done a second one in August 1951, in which, as opposed to the relative dispersion of the first one, he had gone

${ }_{15}$ All of Miguel Fisac's projects for the Dominican Order were
All for this province, in charge of the missions for the Far East. The assignments came from the Provincial Father Sancho, personal friend of Josemaría Escrivá de Balaguer - the founder of Opus Dei- and trainer of the first priests in that institution to which Fisac belonged at the time.

Apart from the Arcas Reales complex and the Alcobendas one, Fisac made a project for the Province of Our Lady of the Rosary of the 1960, as well as the project for the Dominican Mission in Formila in 1960, as well as the project for the Dominican Mission in Formosa in the Holy Cross in Oleiros, in A Coruña.

the Holy Cross in Oleiros, in A Coruña. ${ }_{16}$ Cf. "Colegio Apostólico de los PP. Dominicos en Valladolid", Revista Nacional de Arquitectura, 157 (1955), pag. 3-9 and Severa los PP. Dominicos de Valladolid", Revista Nacional de Arquitectura, 157 (1955), pag. 10-19.

17 Outside the apse, the sculpture of Saint Domingo is an aluminium cast by Jorge Oteiza, who was also the author of the figures by the cross on the back façade. Inside, the group of sculptures with the Lady of the Rosary with Saint Domingo is by José Capuz; the way of the cross reliefs are by Cristino Mallo and the stained-glass windows in the church dealing with rosary topics are by José María de Labra; Francisco Farreras and others made the sculptures on the altars of the side chapels; Susana Polac, made the stone figures at the entrance and the refectory mosaic; Antonio Rodríguez made the altarpiece painting

Intervention by Miguel Fisac in: Several authors, "Sesión de Critica de Arquiturta dedicada a la iglesia de los PP. Dominicos de

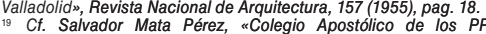
Cf. Salvador Mata Perez, "Colegio Apostolico de los PP. Dominicos", in: Celestino Garcia Braña y Fernando Agrasar Quiroga (eds.), "Arquitectura moderna en Asturias, Galicia, Castilla y León.
Ortodoxia, márgenes y transgresiones", COAA/COAG/COACLE COAL, 1998, pág. 230 .

The architect stated during an interview with Father José María Javierre S.J. published in ARA magazine his opinion on the subject in brief: "The sculpture of the Virgin, between the pulpit and the see, appears as the mediator, someone close to the people and emerging from the people. The cross is above the altar. No further images. The saints to whom the temple is devoted may have their scultures, symbols or writings in the atriums" (Cf. "Las imágenes en el templo. ¿Cuántas? ¿Cuáles? ¿En qué orden?», ARA, 10 (1966), pag. 37. Durng a personal conversation wh the archect, he told me the story of the stained-glass window. It seems that the stained-glass being the sculptor's brother-in-law. Fis to le explained to him what being the sculptor's brother-in-law. Fisac le explained to him what he wanted: a composition only in red hues alluding to the martyrdom. After a series of conversations, an agreement was reached with Fisac's proposals, and Winternitz sent the design to the Lausanne workshops where the stained-glass was made. As they reached Alcobendas
- "once paid and customs-cleared»- Fisac discovered that the design was not the approved one, but one of the very first proposed by the stained-glass maker. There was no possible return, since the stained-glass fitted the design sent by Winternitz to Switzerland. ${ }_{22}$ Cf. Ricardo de la Bastida Bilbao, "La construcción de templos parroquiales en la diócesis de Vitoria", Revista Nacional de Arquitectura, 72 (1947), pag. 346-351.

${ }_{23}$ Eduardo Delgado Orusco, «Porque vivir es difícil. Conversaciones con Javier Carvajal», Camilo José Cela University Publication Service, Avila, 2002; pag. 44 and 53.

${ }^{24}$ Born in Hijar, province of Teruel in 1911 and dead in Summer 2006 in Zaragoza, where he was based for a long time. Francisco Peralt Ballabriga was promoted as Bishop of the Vitoria diocese in 1955. H ${ }_{25}$ The Italian prelate Giacomo Lercaro (Quinto-al-mare/Genoa, 1891 Rome, 1976). Archbishop of Bologne since 1952, was made Cardinal in Rome, 1976), Archbishop of Bologne since 1952, was made Cardinal in
1953. He was intellectually well trained and also aware of the Church's 1953. He was intellectually well trained and also aware of the Church's need to adapt to the culture of the times. He was responsible for the
contest of excellent architects in this task: Le Corbusier, Alvar Aalto, contest of excellent architects in this task: Le Corbusier, Alvar Aalto, the best-read section of the hierarchy. In 1964, after being appointed as moderator of the II Vatican Council- where he stood for the most open 
trend-Cardinal Lercaro was appointed chairman of the "Consilium ad exsequendam constitutionem liturgicam", a body set by the Holy See for the proper interpretation and implementation of liturgical reforms.

${ }_{26}$ "Sesión de Crítica de Arquitectura sobre las nuevas Parroquia de Vitoria", Revista Nacional de Arquitectura, 196 (1958), pag. 1-2. ${ }_{27}$ It should be born in mind that Sota was one of the few professionals -together with Gutierrez Soto or Cabanyes- who used the brick model with Miguel Fisac's patent -for instance, in the already gone house at Doctor Arce Street- consisting in a ceramic piece, similar to ordinary dor Arce Strect-consisting in "a ceramic piece, similar to ordinary double empty brick, but with a slant in the exposed side and a flange in the bottom one which protects the gasket" (Migue Fisac Serna, "Un nuevo ladrillo", in: Francisco Arques Soler, "Miguel Fisac, arquitecto", Pronaos, Madrid, 1996; pag. 66-71.

${ }_{28}$ It is probable that the opinions uttered during the Session of Architecture Critique, where the very bishop of the diocese was present, tipped the scale in favour of Fisac, given that most architects expressly insisted that Fisac's draft project was better than Sota's. Among them were Jenaro Cristos, Antonio Lamela, José Antonio Domínguez Salazar and Rafael Aburto.

29 Miguel Fisac Serna, ulglesia de la Coronación de Nuestra Señora, Vitoria", Arquitectura, 17 (1960), pag. 36.

Senora, Vitoria", Arquitectura, 17 (1960), pag. 36.

${ }^{30}$ Several authors "Las nuevas parroquias de Vitoria. Sesión de Crítica de Arquitecturam, Revista Nacional de Arquitectura, 196 (1958), pag. 7.

$\begin{array}{ll}31 & \text { Ibidem, pag. } 8 . \\ 32 & \text { The cross above the altar is by Pablo Serrano, while the stained- }\end{array}$ 32 The cross above the altar is by Pablo Serrano,
glass windows were made by Francisco Farreras.

${ }_{33}$ Miguel Fisac Serna, "Miguel Fisac", Documentos de Arquitectura, 10 (1989), Monographic issue, pag. 24 and 28.

${ }^{34}$ This expressive term serves both to point out the personal belligerence and the amount of proposals of the architect from $L$ Manch - in particular in the sacred field - and to recall the famous Mancha - in particular in the sacred field - and to recall the famous expression parious researchncoined by Alberto Sartoris to describe those years of our architectural scenario, in which Fisac played a strong role.

35 Francisco Arques Soler, quote, pag. 200

${ }^{36}$ This project mechanism was described by Demetri Porphyrios in order to explain some of Alvar Aalto's works. Certainly, borrowing the "hetherotopia" concept from the philosopher Michael Foucault, Porphyrios remarked Aalto's facility to work with Several formal familie at the same time. This coincidence is significant, to the extent that Fisac never hid the Scandinavian trait of his architecture. The coincidence can also extend to Aalto's and Fisac's shared interest in the religious genre. Cf. Eduardo Delgad genre. Ct. Eduardo Delgado Orusco, "100 años de Alvar Aalto», Nueva Revista de Politica, Cultura y Arte, 62 (1999), pag. 110-114.

${ }^{37}$ Nevertheless, and as opposed to this interest than cannot be waived, we should note that Miguel Fisac projected for the same Madrid-Alcalá diocese the Santamarca parish centre a few month later. It was made of brick, following the general instructions of the Technical Office of Madrid Archbishopric, led then by Jacinto Rodríguez Osuna. They were intent on enlarging their parish facilitie (ct. Rafael Ramón Saiz, "Madrid-Alcalá, una diócesis en construcción [Exhibition on the Parishes Built at Madrid Diocese from 1961 to 1982]. Madrid-Alcalá Diocese, Madrid, 1982). ${ }_{38}$ In this regard, Francisco Javier Sáenz de Oiza had a similar position after his grant in the USA in the late 50s. He was then teaching installations at the ETSAM, and he resorted to similar parameters for explaining the project for the Madrid cathedral by Cabrero \& Aburto at one of the famous Sessions of Architecture Critique organised by Carlos de Miguel with the support of the Revista Nacional de Arquitectura (ct. Several authors, «Proyecto de Catedral en Madrid. Sesión de Crítica de Arquitectura», Rna, 123 (1952), pag. 1-8).

39 Miguel Fisac Serna, "Memoria del proyecto de complejo parroquia de Santa Ana, en Moralataz", pag. 2.

40 Ibidem, pag. 4.

${ }^{41}$ Juan Plazaola Artola, cit., pag. 12.

${ }^{42}$ Loc. Quote.

43 I refer to the parish church of Our Lady of Altamira, built in Madrid for the Carmelite Fathers in 1983.

the Carmelite Fathers in 1983.
${ }_{44}$ Cf. Several authors, "Concurso de anteproyectos de la Iglesia ${ }^{44}$ Cf. Several authors, "Concurso de anteproyectos de la Iglesia
Parroquial de San Esteban Protomártir. Cuenca", Arquitectura, 25 (1961), pag. 13-51.

${ }_{45}$ The following reforms and refurbishments are registered from that time: reform of the Holy Christ's hermit "Saviour of the World", Calzada de Calatrava (1976); restoration of Santo Domingo's tower, Almagro (1980); restoration of Saint Bartholomew's church, Almagro (1980); restoration of the castle-church, Calatrava la Nueva (1980); project for restoring saint ursula's convent, Alcaláde Henares (1980); restoration of

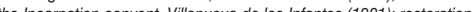

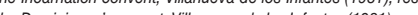
the Franciscan Fathers' church, Jerez de la Frontera (1982); restoration of Saint Augustine's church, Almagro (1984); and restoration of the parish church, Villamanrique (1985).

${ }_{46}$ Cf. Francisco Soler Arques, quote, pag. 281-282.

47 Ibidem, pag. 283.

48 Ibidem, pag. 284-285

49 Ibidem, pag. 296

so Miguel Fisac Serna, "Reflexiones sobre mi muerte», Nueva Utopía, Madrid, 2000; pag. 63
26 "Sesión de Crítica de Arquitectura sobre las nuevas Parroquias de Vitoria", Revista Nacional de Arquitectura, 196 (1958), pág. 1-2.

${ }_{27}$ Tampoco se puede pasar por alto que Sota fue uno de los pocos profesionales -junto a Gutiérrez Soto o Cabanyes - que empleó el modelo de ladrillo patentado por Miguel Fisac - por ejemplo, en la desaparecida casa de la calle del Doctor Arce-consistente en "una pieza cerámica, semejante al ladrillo hueco doble corriente, pero con una inclinación en la cara vista y una pestaña en la parte inferior, que protege la llaga” (Miguel Fisac Serna, "Un nuevo ladrillo», en: Francisco Arques Soler, "Miguel Fisac, arquitecto», Pronaos, Madrid, 1996; pág. 66-71).

${ }^{28}$ Resulta más que probable que las opiniones vertidas en la Sesión de Crítica de Arquitectura, con la presencia física del mismo obispo de la diócesis, inclinase la balanza a favor de Fisac, ya que fueron mayoría los arquitectos que insistieron expresamente en destacar el anteproyecto de Fisac a costa del de Sota. Entre otros, Jenaro Cristos, Antonio Lamela, José Antonio Domínguez Salazar y Rafael Aburto.

${ }_{29}$ Miguel Fisac Serna, "Iglesia de la Coronación de Nuestra Señora, Vitoria», Arquitectura, 17 (1960), pág. 36.

30 Varios, «Las nuevas parroquias de Vitoria. Sesión de Crítica de Arquitectura», Revista Nacional de Arquitectura, 196 (1958), pág. 7.

31 Ibidem, pág. 8.

${ }^{32}$ El crucifijo sobre el altar es obra de Pablo Serrano y las vidrieras de Francisco Farreras.

${ }^{33}$ Miguel Fisac Serna, "Miguel Fisac», Documentos de Arquitectura, 10 (1989), Número monográfico, pág. 24 y 28.

34 Este expresivo término sirve tanto para señalar la beligerancia personal y la cantidad de las propuestas del arquitecto manchego - particularmente en el terreno sacro - como para evocar la célebre expresión -la «furiosa investigación" - con la que Alberto Sartoris caracterizó esos años de nuestro panorama arquitectónico y de la que Fisac participó vigorosamente.

${ }^{35}$ Francisco Arques Soler, cit., pág. 200.

${ }^{36}$ Este mecanismo proyectual ha sido descrito por Demetri Porphyrios para explicar algunas de las obras de Alvar Aalto. En efecto, tomando prestado el concepto de "heterotopía» del pensador Michael Foucault, Porphyrios apuntaba la facilidad de Aalto para trabajar simultáneamente con diferentes familias formales. Esta coincidencia no deja de ser significativa en la medida en que Fisac nunca ocultó la deuda nórdica de su arquitectura. La coincidencia podría extenderse al común interés de Aalto y de Fisac por el género religioso. Cf. Eduardo Delgado Orusco, «100 años de Alvar Aalto», Nueva Revista de Política, Cultura y Arte, 62 (1999), pág. 110-114.

${ }^{37}$ No obstante, y en detrimento de esta irrenunciabilidad, habría que apuntar que para la misma diócesis de Madrid-Alcalá, Miguel Fisac proyectó pocos meses después el complejo parroquial de Santamarca, construido en ladrillo siguiendo las instrucciones generales dictadas por la Oficina Técnica del Arzobispado de Madrid - dirigida entonces por Jacinto Rodríguez Osuna-, empeñada en la tarea de ampliar sus dotaciones parroquiales (cf. Rafael Ramón Saiz, "Madrid-Alcalá, una diócesis en construcción» [Exposición sobre las parroquias creadas en la diócesis de Madrid desde 1961 a 1982], Diócesis de Madrid-Alcalá, Madrid, 1982).

${ }^{38}$ En este sentido, no puede olvidarse un posicionamiento análogo por parte de Francisco Javier Sáenz de Oíza después de su estancia becada en Estados Unidos al filo de la década de los cincuenta. En ese momento, siendo profesor de instalaciones en la ETSAM, acudía a parámetros semejantes para la explicación del proyecto de Catedral para Madrid de los arquitectos Cabrero y Aburto, en una de las célebres Sesiones de Crítica de Arquitectura organizadas por Carlos de Miguel al calor de la Revista Nacional de Arquitectura (cf. Varios autores, "Proyecto de Catedral en Madrid. Sesión de Crítica de Arquitectura», Rna, 123 (1952), pág. 1-8).

${ }^{39}$ Miguel Fisac Serna, "Memoria del proyecto de complejo parroquial de Santa Ana, en Moralataz», pág. 2

40 Ibidem, pág. 4.

41 Juan Plazaola Artola, cit., pág. 12.

42 Loc. cit.

${ }_{43}$ Me refiero a la iglesia parroquial de Nuestra Señora de Altamira, construida en Madrid para los padres carmelitas en 1983.

${ }^{44}$ Cf. Varios autores, "Concurso de anteproyectos de la Iglesia Parroquial de San Esteban Protomártir. Cuenca", Arquitectura, 25 (1961), pág. 13-51.

45 En esta época tenemos registro de, al menos, las siguientes reformas y restauraciones: reforma de la ermita del Santísimo Cristo "Salvador del Mundo", Calzada de Calatrava (1976); restauración de la torre de Santo Domingo, Almagro (1980); restauración de la iglesia de San Bartolomé, Almagro (1980); restauración de la iglesia-castillo, Calatrava la Nueva (1980); proyecto de restauración del convento de Santa Úrsula, Alcalá de Henares (1980); restauración del convento de la Encarnación, Villanueva de los Infantes (1981); restauración del convento de las dominicas, Villanueva de los Infantes (1981); restauración de la iglesia de los padres franciscanos, Jerez de la Frontera (1982); restauración en la iglesia de San Agustín, Almagro (1984); y restauración de la iglesia parroquial, Villamanrique (1985).

${ }^{46}$ Cf. Francisco Soler Arques, cit., pág. 281-282.

47 Ibidem, pág. 283.

48 Ibidem, pág. 284-285

49 Ibidem, pág. 296.

${ }^{50}$ Miguel Fisac Serna, «Reflexiones sobre mi muerte», Nueva Utopía, Madrid, 2000; pág. 63. 